[DOI: 10.24214/jecet.A.9.1.0529.]

Juurnal of Enviranmental Science, Computer Science and Engineering \& Technology

An International Peer Review E-3 Journal of Sciences and Technology

Available online at www.jecet.org

Section A: Environmental Science

Research Article

\title{
Water balance parameters estimation through empirical methods in a coastal ungauged catchment in Eastern - Central Greece
}

\author{
${ }^{1}$ Lappas Ioannis and ${ }^{2}$ Kallioras Andreas
}

\begin{abstract}
${ }^{1}$ Dr. Hydrogeologist, General Secretariat of Natural Environment and Water, Department of Protection and Management of Water Environment, Division of Surface and Ground Waters, Amaliados 17 Str., Ambelokipi-Athens, P.C. 11523
\end{abstract}

${ }^{2}$ Assistant Professor, National Technical University of Athens, School of Mining and Metallurgical Engineering, Laboratory of Engineering Geology and Hydrogeology, Heroon Polytechniou 9 Str., Zografou-Athens, P.C. 15780,

Received: 20 October 2019; Revised: 22 November 2019; Accepted: 03 December 2019

\begin{abstract}
The results of a water balance parameters using empirical methods in the area of Atalanti river basin in central-eastern Greece, are presented in this essay. The major objective of this research study was to evaluate the currently applied process for estimating water balance characterizing the hydrological regime. Once the measurements of the hydrological balance components are complete, the analysis of the hydrology of a basin is best approached through the water budget. The water availability of a region is one of the most significant considerations in both the spatial plans and the evaluation in providing sustainable water resources. This paper considers that water balance method is the most fundamental and appropriate tool in water availability estimation. Estimation of groundwater balance of an area requires estimation of all individual inflows to and outflows from a groundwater system and change in groundwater storage over a given period of time. Input is likely to be mainly rainfall but may include river inflow or groundwater inflow from an adjacent basin, whereas output includes evaporation, transpiration, river and groundwater discharge into the sea and/or river, while storage changes include increases in soil moisture and groundwater storage. Also, accurate and detailed information of hydrological balance is actually needed to develop strategies for sustainable use and
\end{abstract}


management of water resources. Available climatic data were used as input to calculate the water balance for a unit area catchment. The water balance produced quantitative assessments results of the water cycle and provided better understanding of the surface and groundwater interactions. The results showed that the hydrological balance was strongly dependent on the intensity of agricultural activity (almost 96\%) within the basin. The increasing water needs in irrigation require a specifically adapted hydrological model in order to address water management issues. An actual evapotranspiration was found as a main water loss element among the water cycle components due to large-scale agricultural irrigation activities corresponding to $73 \%$ of the total water budget as an average. Once calculated sustainable groundwater management and rational use of groundwater can be implemented since groundwater abstractions can be controlled. Finally, all the water balance components were spatially distributed in a GIS environment to visualize the results.

Keywords: hydrological balance components; water budget; water availability; quantitative assessment; water needs; spatial distribution.

\section{INTRODUCTION}

In nowadays, continuous population growth and urbanization have increased water needs and strained water resources availability around the world. An assessment of the available water resources via a water balance model is a prerequisite for the analysis of water resources stress and for the subsequent adoption of proper management strategies so as to sufficiently ensure the water supply according to demands and needs, spatially distribute water, protect from flood or drought, maintain water quality and deal with conflicts between different users and stakeholders as well. Precipitation provides the main component of the surface water and groundwater resources, whereas evapotranspiration comprises a significant hydrological loss ${ }^{1}$. In order to ensure practical applicability, all the applied models require simple simulation procedure and parameter estimation based on available climate and catchment characteristics ${ }^{2}$. Monthly water balance models were first introduced by Thronthwaite ${ }^{3}$, followed by Thornthwaite and Mather ${ }^{4}$, in order to establish realistic and deterministic procedures for partitioning rainfall into evapotranspiration and water surplus. Although monthly water balance models depend on many parameters and require a large number of data, a limited number of parameters seems sufficient to reproduce the measured outputs of the hydrological system ${ }^{5,6}$. The purpose of this paper is to investigate the hydrological components of the Atalanti river basin in eastern-central Greece. The geomorphological aspects of the area, which combines both mountainous and coastal zones and the increasing water needs for irrigation purposes, require an assessment of regional water resources potential. The model is specifically adapted to regional characteristics and to the sparseness and limitation of available data concerning the study area.

The water balance or the hydrological balance of a particular area results from the study of the water cycle and more specifically from its quantitative approach. The assessment of the aquifers' water balance aims to determine all water inflows and outflows in combination with storage changes over time and water needs per use under steady or non-steady flow conditions. The water balance is described by Fetter, ${ }^{7} 2001$; Freeze \& Cherry ${ }^{8}$ :

$$
\text { Inflows }(I)=\text { Outflows }(O) \pm \text { Storage }(\Delta S)
$$

or

$$
\frac{d S(t)}{d t}=I(t)-O(t)
$$


In time unit the water inflows into an aquifer are mainly derived from $(a)$ the part of the rainwater that leaves the ground infiltrating into the aquifers, $(b)$ the surface runoff infiltration, $(c)$ the various groundwater lateral recharge from adjacent aquifers or different recharge boundaries (e.g., faults, fractures), (d) the return irrigation flows or the surface and/or groundwater enrichment processes through artificial recharge, $(e)$ the losses of sewage and irrigation networks, while outflows are distinguished into $(i)$ the groundwater abstractions through various artificial works, such as boreholes and wells, (ii) the groundwater discharge, (iii) the hydraulic communication to other adjacent aquifers depending on the prevailing hydrodynamic and boundary conditions. The concept of an area's integrated water resources management includes both the study of the quantitative and qualitative groundwater and surface water status. For that purpose, the hydrological balance sufficient knowledge of the regional research area is definitely appropriate. The study of an area's water balance requires the aqcuisition of systematic measurements of hydrometeorological parameters such as rain, temperature, evaporation, sunshine, solar radiation, relative humidity, wind, runoff, etc. as well as the processing and correlation of the data for each parameter ${ }^{9,10}$.

\section{MATERIALS AND METHODS}

2.1. Study Area and Meteorological Data: The Atalanti watershed lies in Eastern-Central Greece (between $21^{0} 44^{\prime}-24^{0} 39^{\prime}$ longitudes and $37^{0} 45^{\prime}-39^{0} 29^{\prime}$ latitudes) covering an area of $248 \mathrm{~km}^{2}$ (Fig.1). The drainage has flat relief mainly consisted of lowlands with slopes up to $20^{\circ}$ while in highlands the slopes reach $55^{\circ}$. The study area is surrounded by hilly and mountainous ranges (Mt. Chlomo) and washed by the sea at the East. The semi-mountainous topographical zone accounts for $4.5 \%$ (600$800 \mathrm{~m})$ while the flat areas account for $39.5 \%(0-200 \mathrm{~m})$ mostly concerning the coastal areas. Also, the hilly and semi-hilly areas occupy almost 54\% (200-600m) of the basin. Moreover, the basin's elevation starts from the sea level ending up to $1073 \mathrm{~m}$ above sea level (a.s.l.) crossed by a well developed, dendritic drainage discharging into Aegean Sea. At the coastal region the flat and hilly relief prevails covering $76 \%$ of the basin..
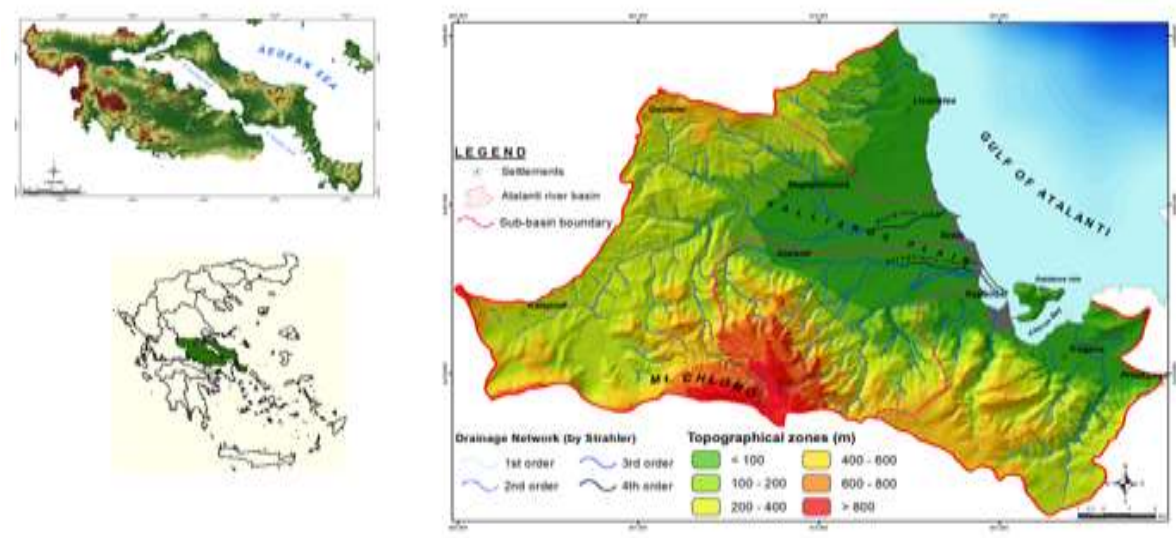

Fig.1: The site location of the study area, the digital elevation model (DEM) of EasternCentral Greece and the topographical zones of Atalanti river basin with its contributing drainage network.

Also, only temporal streams exist, such as Alarginos, Karagkiozis ( $4^{\text {th }}$ order by Strahler) and Ag. Ioannis $\left(3^{\text {rd }}\right.$ order by Strahler) flowing mostly during winter and spring after heavy rainfall events 
forming $\mathrm{V}$-shape rejuvenated valleys due to intensive tectonicsWithin the mountainous ranges the first $\left(1^{\text {st }}\right)$ and second $\left(2^{\text {nd }}\right)$ order streams form steep slopes with deep river bed. Generally speaking, the drainage within the lowlands is considered dense due to semi-permeable formations (e.g. clays, silt, fine sand, etc.) while in the rocky areas the intensive and active tectonics has formed a significantly sparse drainage ${ }^{11,12}$.

Climatically speaking, the study area is characterized by mild, wet winters and hot, dry summers (typical Mediterranean climate with $\mathrm{C}_{\mathrm{sa}}$ type according to Köppen classification) with the mean annual precipitation and the air temperature equals to $710.1 \mathrm{~mm}$ and $16.8^{\circ} \mathrm{C}$ respectively ${ }^{13-16}$. Over $70 \%$ of the precipitation takes place from October to April with rainfall non-uniformity between the lowlands and highlands with observed higher values in the mountains and lower ones in the valleys, as expected (Fig.2). Moreover, monthly hydrometeorological data such as temperature and precipitation were obtained from the Hellenic National Meteorological Service (HNMS) and the Ministry of Environment and Energy from various gauging stations within and nearby the study area for a significant time period (long time series dataset from 1981 to 2014) so as the temperature as well as the rainfall's spatial distribution and intensity to be derived as they are the main factor for water budget calculation. The required base and derived thematic spatial maps were pre-processed, analyzed and integrated together in terms of watershed boundary in a Geographical Information System (GIS) environment eventually transformed into a grid spatial database ${ }^{17,18}$.
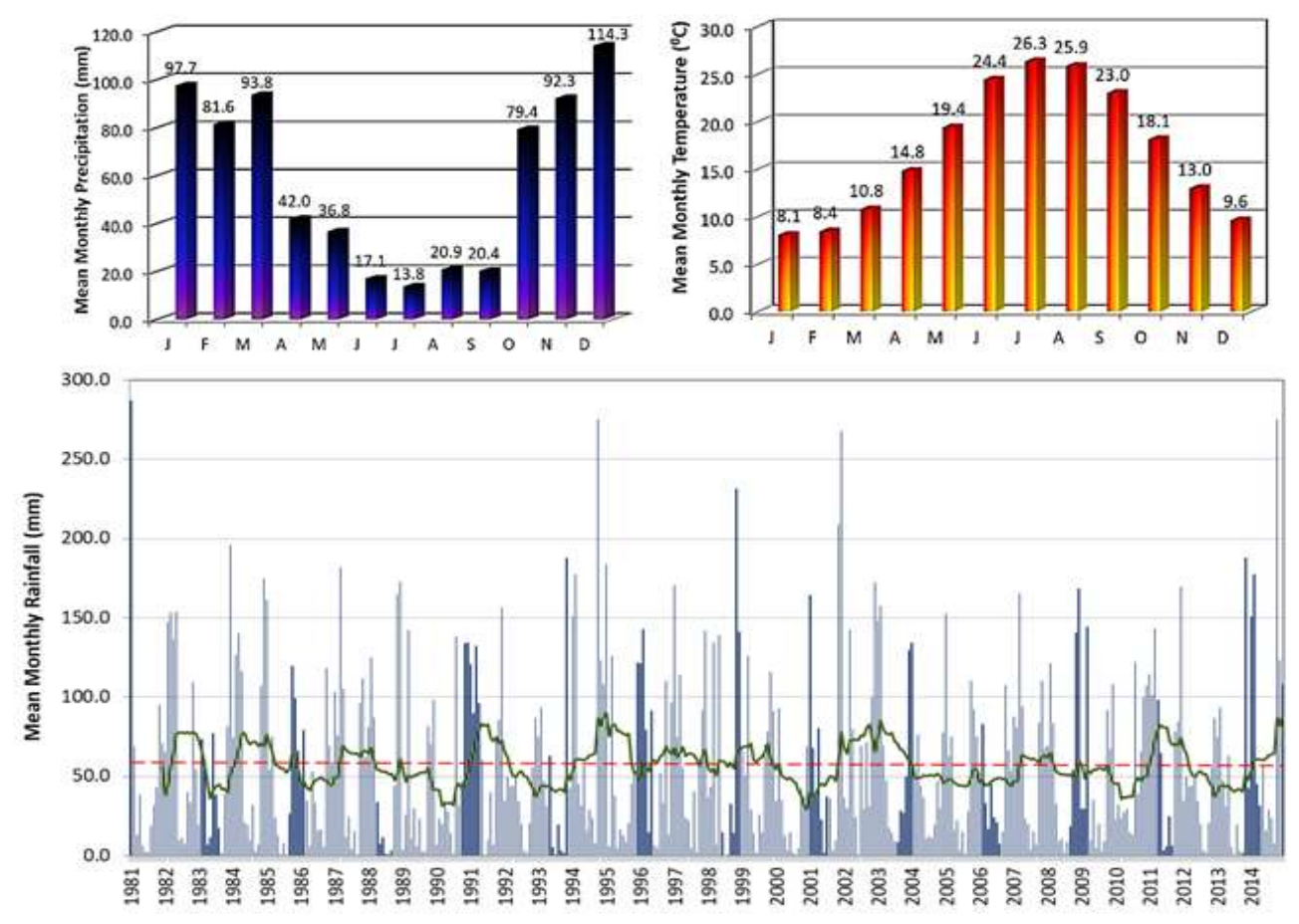

Fig.2: Mean monthly rainfall (up left), mean monthly temperature (up right) and analytical mean monthly rainfall values in the study area from all the gauging stations (down). The red dashed line shows the average precipitation value of the time series (1981-2014) and the green solid one the 12month moving average

2.2. Geological Regime - Tectonics: Geologically speaking, the study area is consisted of post alpine deposits covering the lowlands ${ }^{19}$. As illustrated in Fig.3, the regional area is composed by several rock types including shales, schists, sandstones and conglomerates (metamorhic-ultrabasic rocks), 
dolomites, limestones, ophiolitic rocks (gabbro, diabases, peridotites, serpentines) and flysch comprising the bedrock along the eastern, northern and southern outcrops of the alluvial plain ${ }^{19}$. Also, post-alpine unconsolidated sandy and marly formations such as marls, calcareous marls, marly limestones, clays, sandy loams, sandy marls, lignitic beds, conglomerates with sandstones intercalations, lacustrine deposits, coastal sandy and clay-sandy sediments, debris cones are mainly located in the coastal region and recent, loose sediments of silts, sands and pebbles are deposited at the basin's lower parts (Fig.3). Tectonically speaking, the large-scale faulting zones in Atalanti basin with West-North West and North-North East directions are the main features of the regime that took place during Miocene.

Tectonically speaking, the most significant feature is the large-scale faulting zones with WestNorthWest and North-NorthEast directions reactivating many other faults also forming fractures, fissures, cracks and other discontinuities within the rocky beds ${ }^{20-22}$. Finally, the Atalanti normal faulting zone of $30 \mathrm{~km}$ length with NW-SE direction has reactivated many other faults giving significant earthquakes of which two of them took place on April 1894 A.D. with magnitudes of 6.4 and 6.9.

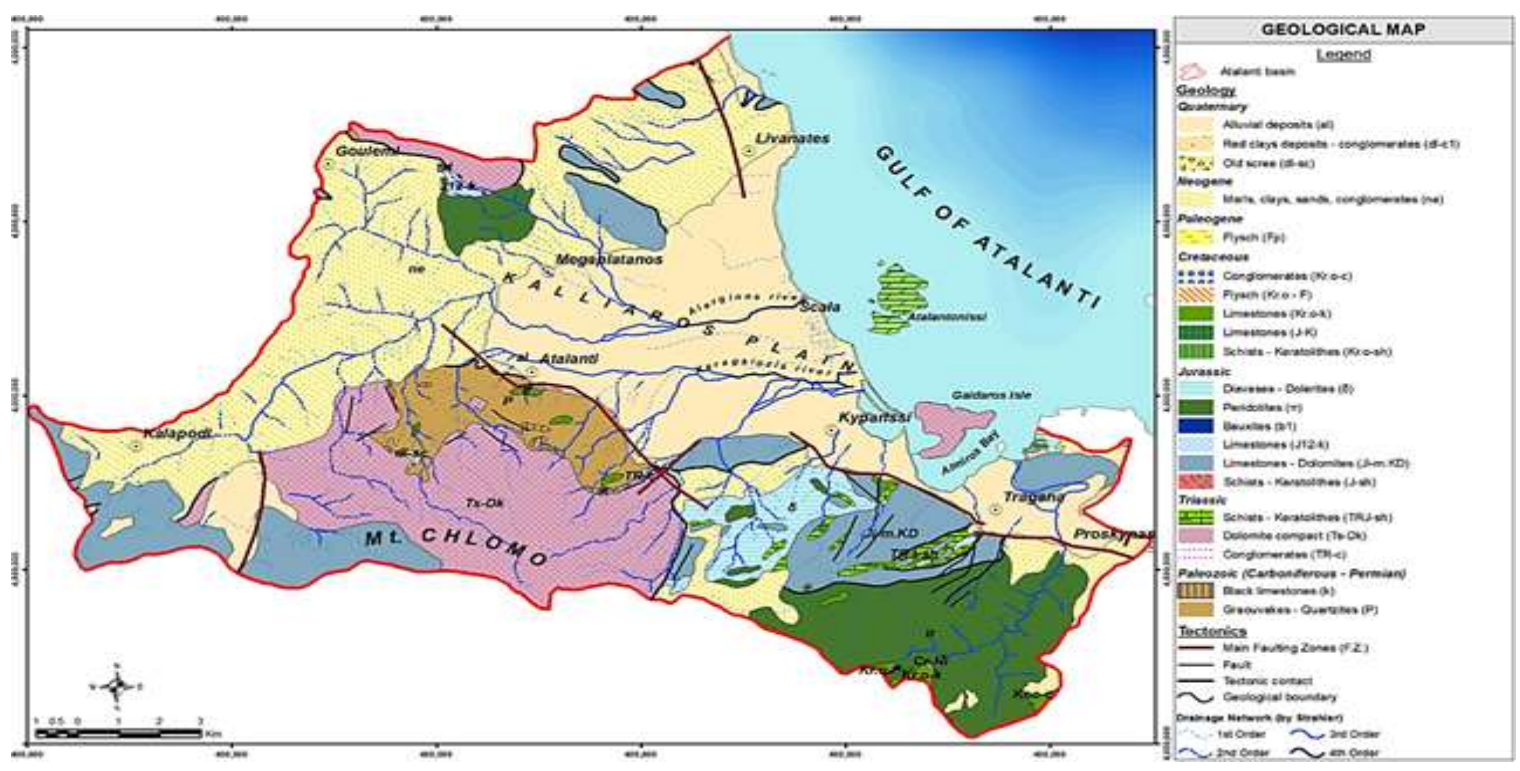

Fig.3: Geological map of the study area (Maratos et al. ${ }^{19}$ with modifications by the authors).

2.3. Water Balance Equation: The knowledge of an area's hydrological balance is of prime importance for any hydrogeological survey, as well as for any effort to sustain the water potential. The river basin's water balance is expressed as the difference between inflow and outflow with the rate of change in water storage $\Delta S$ at a given time $\Delta t$. The water balance parameters are the precipitation, the evapotranspiration, the surface runoff, the lateral recharge and the infiltration as well. Also the parameters of great importance, depending on the hydrogeological environment, are the springs' discharge and the water abstractions for various uses such as irrigation, water supply, industrial use, etc (Fig.4). Moreover, the estimation of the groundwater natural recharge and the irrigation returns, in unconfined aquifers, is very important because it contributes to the estimation of their renewable water resources and consequently their management. The water distribution within a watershed can be described by the following equation ${ }^{7,23}$ : 


$$
P+Q=E T_{a}+R+I \pm \Delta S \pm \Delta q
$$

where,

$\boldsymbol{P}=$ the precipitation; $\boldsymbol{Q}=$ the basin's external recharge; $\boldsymbol{E} \boldsymbol{T}_{\boldsymbol{a}}=$ the actual evapotranspiration

$\boldsymbol{R}=$ the surface runoff; $\boldsymbol{I}=$ the infiltration or groundwater natural recharge)

$\Delta S=$ the Storage and; $\boldsymbol{\Delta q}=$ the water injections or abstractions due to human intervention.

In most cases, the factors indirectly determined based on the water balance are the surface runoff and/or the infiltration that are difficult to be directly quantified by measurements and observations due to the lack of monitoring stations. In the present study, factors, namely, the precipitation, the actual evapotranspiration and the infiltration are first determined either by the measured data processing or through references and hence the surface runoff is indirectly calculated. The parameters of $\Delta S$ and $Q$, on an over-annual basis, tend to be minimized provided that the basins are autonomous systems. The above mentioned variables can be expressed in water height $(\mathrm{mm})$ or water volume $\left(\mathrm{m}^{3}\right)$ as well as in percent $(\%)$ linked by a cause-effect relationship, which is complex and non-unique ${ }^{1}$. To calculate a reliable hydrological balance, it is necessary to know the amount of annual rainfall, the actual evapotranspiration, the amount of groundwater discharge and the water abstractions. In this approach, the use of Geographic Information Systems is crucial, as it allows the calculation of the various parameters quickly, reliably and as accurately as possible.
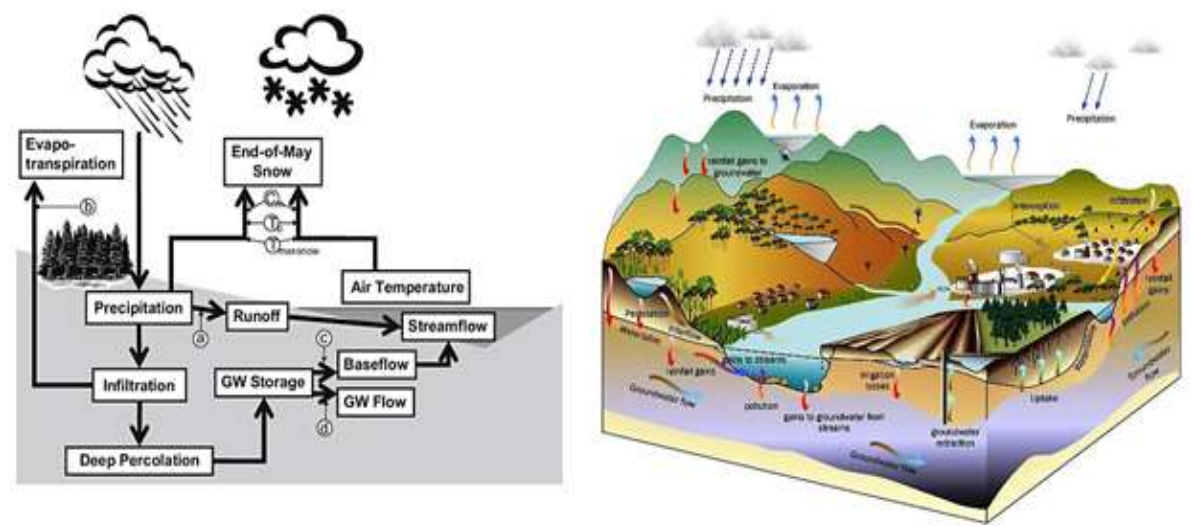

Fig.4: Schematic presentation of the water balance parameters ${ }^{14}$.

However, the estimation of the water balance cannot be performed with complete accuracy, due to the lack of critical hydrometeorological data. Modern computational methods usually require input data, such as climatic and microclimate data (rain, relative humidity, wind speed, solar radiation, etc.) as well as surface runoff measurements at selected streams at least daily or even hourly. In particular, with regard to the water balance estimation and to aquifer water discharges, continuous recordings of both spring discharges and water abstractions from boreholes are required. Therefore, the present paper attempts to make, as far as possible, an accurate quantitative water balance estimation using classic and empirical approximations and methodologies as well as references through data from the nearest meteorological stations. 


\section{RESULTS AND DISCUSSION}

\subsection{Water Balance Parameters:}

Precipitation: In order to calculate the research area's meteoric water volume, the relationship relating the elevation to the rain gradient for the time period 1981 - 2014, was first determined (Fig.5 up). This relationship since a strong correlation exists was applied to the survey area's digital elevation model (DEM) derived from the digitization of the elevation curves with equidistant $20 \mathrm{~m}$ via Geographic Information System (GIS).
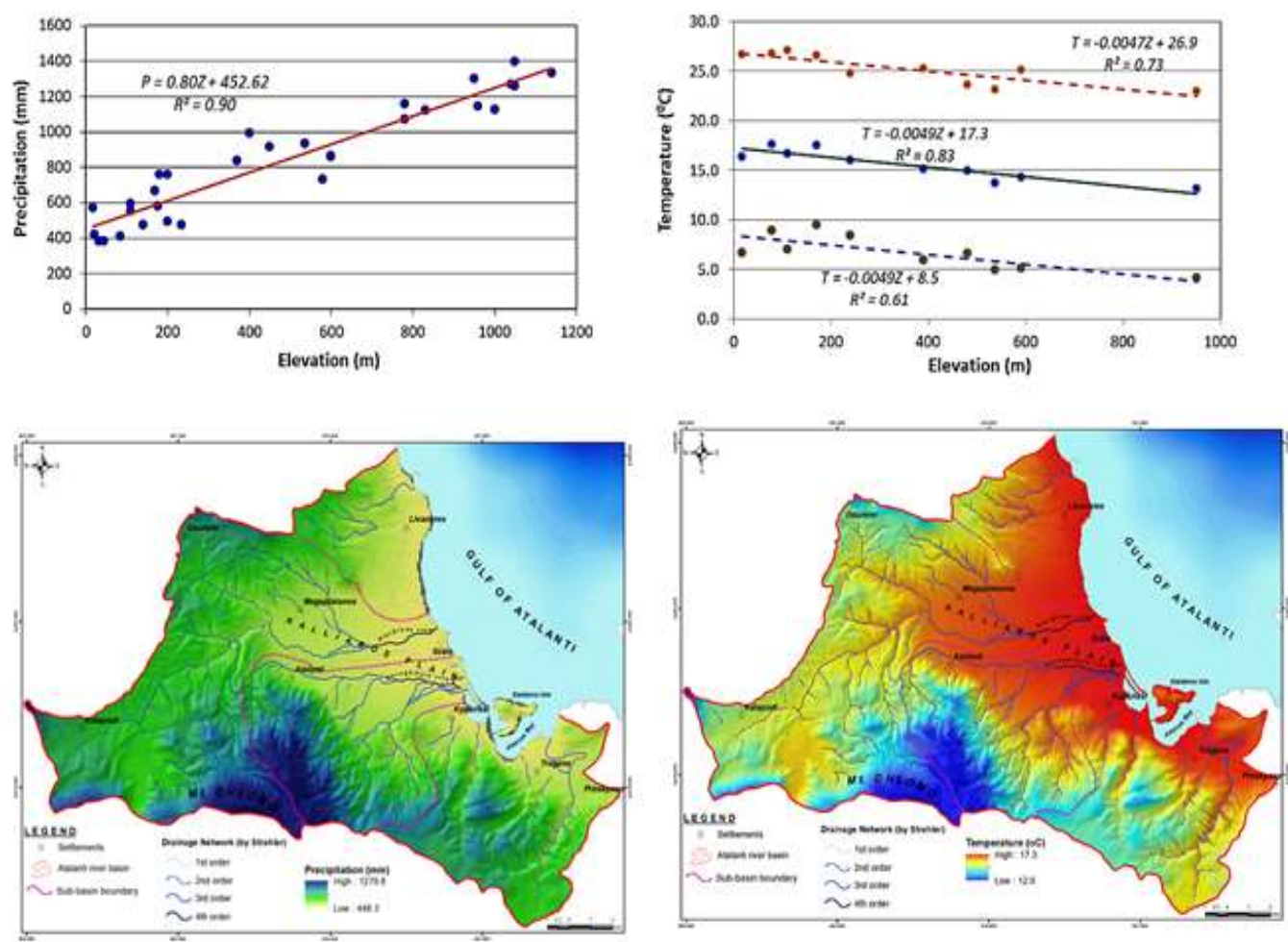

Fig.5: Rain and temperature correlation with elevation (up) and precipitation - temperature spatial distribution (down) in Atalanti river basin.

Subsequently, the surface area of each unit square of the digital terrain model was multiplied by the corresponding rain amount and the products (Fig.5 down) were aggregated across the entire basin or geological formation. The results of this methodology are considered to be more accurate than the traditional methods of the isohyetal curves and Thiessen polygons, since the calculation is done separately for each pixel of the digital terrain model, which in this case is $25 \times 25 \mathrm{~m}$ and not for the surface between two successive curves or a Thiessen polygon, the average rain volume being used for a relatively large area.

Rainfall volume distribution for each sub-basin and geological formation is presented in Tables $\mathbf{1}$ and 2, respectively. As shown in Table 1, the average annual precipitation volume for the period 1981 2014 was approximately $178.2 \times 10^{6} \mathrm{~m}^{3}$ and the mean surface rain for the same period was estimated at $714.1 \mathrm{~mm}$, very close to the arithmetic mean of $710.1 \mathrm{~mm}$. 
Table 1: Mean annual precipitation in area's sub-basins.

\begin{tabular}{lccccc}
\hline Basin & Area $\left(\times \mathbf{1 0}^{\mathbf{6}} \mathbf{m}^{\mathbf{2}}\right)$ & $\begin{array}{c}\text { Minimum } \\
(\mathbf{m m})\end{array}$ & $\begin{array}{c}\text { Maximum } \\
(\mathbf{m m})\end{array}$ & Mean $(\mathbf{m m})$ & $\begin{array}{c}\text { Precipitation } \\
\text { volume }\left(\times \mathbf{1 0}^{\mathbf{6}} \mathbf{m}^{\mathbf{3}}\right)\end{array}$ \\
\cline { 3 - 5 } & 109.1 & 448.3 & 1279.8 & 688.9 & 83.47 \\
Alarginos & 55.2 & 448.3 & 1279.8 & 695.7 & 42.57 \\
Karagkiozis & 55.4 & 448.3 & 827.8 & 637.1 & 35.29 \\
Agios & 29.8 & 448.3 & 917.8 & 669.1 & 16.84 \\
Ioannis & $\mathbf{2 4 9 . 5}$ & & & & $\mathbf{1 7 8 . 1 7}$ \\
Others & & & & & \\
$\boldsymbol{S} \boldsymbol{M}$ & & & & &
\end{tabular}

From Table 2 and Fig.6 it is observed that the highest precipitation rate corresponds to the carbonate formations $(34.9 \%)$ followed by the Neogene deposits $(28.6 \%)$, the alluvial deposits $(16.3 \%)$ and the basic-ultrabasic rocks $(13.9 \%)$. The remaining $6.3 \%$ of the rain is distributed to the graouvakes quartzites - tuffs $(5.4 \%)$, to the schists - keratolithes - phyllites $(0.8 \%)$ and to the conglomerates $(0.12 \%)$, while a very small proportion $(0.03 \%)$ corresponds to bauxites $-\mathrm{Fe}-\mathrm{Ni}$ ore.

Table 2: Mean annual precipitation equivalent volume per geological formation

\begin{tabular}{|c|c|c|c|c|c|c|}
\hline \multirow[b]{2}{*}{ Geological Formation } & \multirow{2}{*}{$\underset{\left(\times 10^{6} \mathrm{~m}^{2}\right)}{\text { Area }}$} & \multicolumn{3}{|c|}{ Precipitation } & \multirow{2}{*}{$\begin{array}{c}\text { Precipitation } \\
\text { volume } \\
\left(\times 10^{6} \mathrm{~m}^{3}\right)\end{array}$} & \multirow{2}{*}{$\begin{array}{c}\text { Percen } \\
(\%)\end{array}$} \\
\hline & & $\begin{array}{c}\text { Minimum } \\
(\mathrm{mm})\end{array}$ & $\begin{array}{l}\text { Maximum } \\
(\mathrm{mm})\end{array}$ & $\begin{array}{l}\text { MÉं̄ } \\
(\mathbf{m m})\end{array}$ & & \\
\hline Alluvial deposits & 58.7 & 448.3 & 804.7 & 494.2 & 29.01 & 16.3 \\
\hline Bauxites - Fe-Ni ore & 0.06 & 657.3 & 994.3 & 776.8 & 0.05 & 0.03 \\
\hline Neogene deposits & 72.4 & 448.3 & 893.7 & 634.3 & 51.03 & 28.6 \\
\hline Carbonate rocks & 71.9 & 448.3 & 1279.8 & 800.1 & 62.22 & 34.9 \\
\hline Conglomerates & 0.3 & 620.7 & 828.9 & 716.8 & 0.22 & 0.12 \\
\hline $\begin{array}{l}\text { Schists-Keratolithes- } \\
\text { Phyllites }\end{array}$ & 2.0 & 450.6 & 913.2 & 708.3 & 1.39 & 0.8 \\
\hline Flysch & 0.03 & 759.5 & 771.2 & 764.4 & 0.02 & 0.01 \\
\hline $\begin{array}{l}\text { Graouvakes - Quartzites - } \\
\text { Tuffs }\end{array}$ & 11.7 & 513.0 & 956.1 & 731.6 & 9.54 & 5.4 \\
\hline Basic - Ultrabasic rocks & 32.4 & 450.6 & 886.6 & 685.6 & 24.69 & 13.9 \\
\hline SUM & 249.5 & & & & 178.17 & 100.0 \\
\hline
\end{tabular}
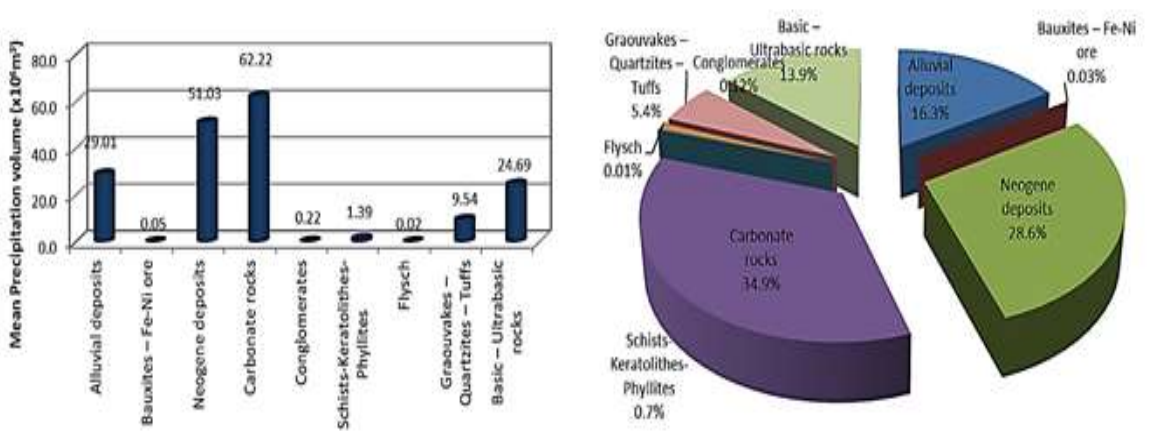

Fig.6: Mean annual rainfall volume (1981 - 2014) (left) and rainfall percent per geological formation (right). 
Evapotranspitation Methods: Evaporation is defined as the amount of water that returns to the atmosphere under the combined action of evaporation and transpiration, with the evaporation being the transport process, in the form of water vapor from the ground surface to the atmosphere with solar energy and radiation while transpiration is defined as the set of processes by which water passes from liquid to gaseous phase through plants. The evapotranspiration can be measured either as the water loss rate from a soil profile or as the vapor abstraction rate from the atmosphere and is a function of soil moisture including the total amount of the evaporated water used by plants. This is a particularly important factor regulating the percentage of water remained for surface runoff and infiltration. The evapotranspiration depends on many factors, such as the soil-air temperature, the humidity, the wind speed, the barometric pressure, the solar radiation, the vegetation cover, the soil granulometry, the geological formations' porosity, etc. The potential evapotranspiration is defined as the water amount that would be evaporated or used by plants for the transpiration process if the water resources were sufficient to replace the losses. On the contrary, the actual evapotranspiration is considered to be the actual water loss from the soil surface by the evaporation and transpiration processes under the existing climate, the vegetation cover and the soil moisture conditions.

Many methods have been developed for the evapotranspiration estimation (potential and actual) and numerous empirical formulas have been proposed, however, not fully covering and explaining the process. Thus, various relationships have emerged, ranging from empirical to modern, analytical, examining the energy balance of the system under study requiring detailed climatic data and measurements. In this paper, many well-known methods have been used to calculate potential evapotranspiration, such as Penman - Montieth $^{24}$, Thornthwaite ${ }^{3}$ (1948), Blaney - Criddle ${ }^{25}$, Hargreaves ${ }^{26}$, Doorenbos - Pruitt ${ }^{27}$ and Priestley - Taylor ${ }^{28}$, while Turc's equations (corrected and not corrected, 1951, 1954, 1961) ${ }^{29-31}$, Santoro ${ }^{32}$, Coutagne $^{33}$, Burdon - Papakis ${ }^{34}$ and Thornthwaite Mather ${ }^{4}$ have been used to calculate the actual evaporation.

\section{Potential Evapotranspitation}

(A) Penman - Montieth ${ }^{24}$ : the evapotranspiration $E T_{p}$ is given by the following equation:

Where,

$$
E T_{p}=\frac{\Delta}{\Delta+\gamma} \cdot \frac{R n}{\lambda}+\frac{\gamma}{\Delta+\gamma} \cdot F(u) \cdot D
$$

$\Delta=$ the slope of the saturated water vapor in $\mathrm{hPa} /{ }^{\circ} \mathrm{C}, \Delta=\frac{4098 \cdot e_{s}}{(T+237.3)^{2}}$

$\boldsymbol{e}_{s}=$ the water vapor saturation pressure in $\mathrm{hPa}\left(e_{s}=6.11 \cdot e^{\frac{17,27 \cdot T}{T+237,3}}\right)$

$\gamma=$ the cooling coefficient defined by the equation: $\gamma^{\prime}=\gamma\left(1+0.33 u_{2}\right)$

$\lambda=$ the latent heat evaporation in $\mathrm{kJ} / \mathrm{kg}\left(\lambda=2501-2.361 T_{s}\right)$

$\boldsymbol{F}(\boldsymbol{u})=$ the wind velocity function in $\mathrm{hPa} \mathrm{kg} / \mathrm{m}^{2} \mathrm{~d} F(u)=\frac{90}{T+275} u_{2}$

Where,

$\boldsymbol{u}_{2}=$ the wind velocity in $2 \mathrm{~m}$ height above the ground in $\mathrm{m} / \mathrm{s}$;

$\boldsymbol{D}=$ the saturation deficit in $\mathrm{hPa}\left(D=e_{s}-e=e_{s}-U e_{s}\right)$

where, 
$\boldsymbol{U}=$ the relative humidity

$\boldsymbol{R}_{n}=$ the algebraic sum of incoming-outcoming radiation in $\mathrm{kJ} / \mathrm{m}^{2} \mathrm{~d}\left(R_{n}=S_{n}-L_{n}\right)$

where,

$S_{n}=$ the algebraic sum of the incoming - reflective microwave radiation in $\mathrm{kJ} / \mathrm{m}^{2} \mathrm{~d}$

$$
S_{n}=(1-r) \cdot S_{o}\left(0.29 \cdot \cos \varphi+0.55 \frac{n}{N}\right)
$$

where,

$\boldsymbol{r}=$ the coefficient of reflection which equals to 0.25

$S_{\boldsymbol{o}}=$ the shortwave radiation of the outer boundary of the atmosphere in $\mathrm{kJ} / \mathrm{m}^{2} \mathrm{~d}$ which is a function of the month latitude

$\boldsymbol{\Phi}=$ the region's latitude in degrees

$\boldsymbol{n}=$ the sunshine in hours

$\boldsymbol{L}_{\boldsymbol{n}}=$ the clean microwave radiation in $\mathrm{kJ} / \mathrm{m}^{2} \mathrm{~d}\left[L_{n}=e_{n} f_{L} \sigma(T+273)^{4}\right]$

Where,

$\sigma=$ the constant of the heat emission law which equals to $\sigma=4.9 \times 10^{-6} \mathrm{~kJ} / \mathrm{m}^{2} \mathrm{k}^{4} \mathrm{~d}$

$\boldsymbol{e}_{n}=$ is given by the equation $\left(e=U e_{s}\right): e_{n}=0.56-0.09 e^{0.5} \Leftrightarrow e_{n}=0.56-0.09\left(U e_{s}\right)^{0.5}$ and

$f_{L}=$ is given by the equation: $f_{L}=0.1+0.9 \frac{n}{N}$.

(B) Thornthwaite ${ }^{3}$ : the method estimates the monthly evapotranspiration based on the mean monthly temperature given by the equation :

$$
E T_{p}=16 \cdot\left(\frac{10 T_{i}}{J}\right)^{a} \cdot \frac{\mu \mathrm{N}}{360}
$$

where,

$\boldsymbol{E}_{\boldsymbol{p}=}$ the potential evapotranspiration (mm/month)

$\boldsymbol{T}_{\boldsymbol{i}}=$ the mean monthly temperature $\left({ }^{0} \mathrm{C}\right)$

$\boldsymbol{\mu}=$ the number of days

$N=$ the mean astronomic day duration

$\boldsymbol{J}=$ the annual temperature index and

$\boldsymbol{a}=$ an empirical parameter based on $J$ index.

The temperature index $J$ is given by the equation: $J=\sum_{i=1}^{12} j_{i}$, the mean temperature index $j_{i}$ is a

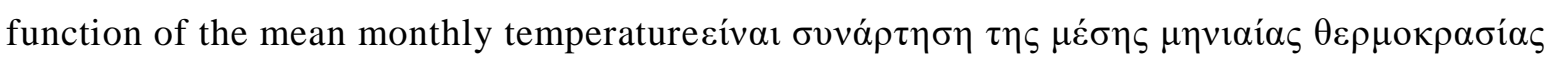
$\sigma v ́ \mu \varphi \omega v \alpha \mu \varepsilon \tau \eta v \varepsilon \xi i \sigma \omega \sigma \eta j_{i}=0.09 \cdot \mathrm{T}_{i}^{1.5}$, while the parameter a is given by the equation $a=0.000000675 \cdot J^{3}-0.0000771 \cdot J^{2}+0.01792 \cdot J+0.49239$. 
(C) Blaney - Criddle ${ }^{25}$ : the evapotranspiration $E T_{p}$ is given by the following equation :

$$
E T_{p}=k F=k \frac{(1.8 \cdot T+32) \cdot p}{3.94}
$$

where,

$\boldsymbol{k}=$ the crop coefficient

$\boldsymbol{T}=$ the mean monthly temperature in ${ }^{0} \mathrm{C}$ and

$\boldsymbol{p}=$ the percentage of the daylight hours of the month.

(D) Hargreaves ${ }^{26}$ : this method uses only temperature data input (maximum, minimum and mean monthly) based on the equation:

$$
E T_{p}=0.0023\left(S_{o} / \lambda\right) \times\left(T_{m}+17.8\right) \times\left(T_{\max }-T_{\min }\right)^{0.5}
$$

where,

$S_{\boldsymbol{o}}=$ the extraterrestrial radiation in $\mathrm{kJ} / \mathrm{m}^{2} \mathrm{~d}, \lambda$ the latent heat evaporation in $\mathrm{kJ} / \mathrm{kg}$

$\boldsymbol{T}_{\boldsymbol{m}}=$ the mean monthly air-temperature in ${ }^{\circ} \mathrm{C}$ and

$\boldsymbol{T}_{\boldsymbol{m a x}}-\boldsymbol{T}_{\boldsymbol{m i n}}=$ the difference between the maximum and minimum temperature in ${ }^{\circ} \mathrm{C}$. This method provides more accurate results when daily temperature values are concerned.

(E) Doorenbos - Pruitt ${ }^{27}$ : in this method $E T_{p}$ is given by the equation:

$$
E T_{p}=c\left[\frac{\Delta}{\Delta+\gamma} \cdot \frac{R n}{\lambda}+\frac{\gamma}{\Delta+\gamma} \cdot F(u) \cdot D\right]
$$

where,

$c=$ the reduction coefficient based on the maximum relative humidity, the solar radiation, the wind velocity during the daylight and the wind velocity during the night. The variable $F(u)$ is given by the equation $F(u)=0.27(1+0.86 u)$.

(F) Priestley - Taylor ${ }^{28}$ : in this method $E T_{p}$ is given by the equation:

$$
E T_{p}=a_{e} \frac{\Delta}{\Delta+\gamma} \cdot \frac{R n}{\lambda}
$$

where,

$\boldsymbol{\alpha}_{e}=$ an arithmetic constant which equals to 1.3 . The above equation uses only the energy term of PENMAN - MONTIETH method, increased by $30 \%$, completely deleting the transfer term ${ }^{35}$.

A summary table (Table 3) is given below presenting the calculations of the mean potential evapotranspiration per month by all methods and for all available hydrometeorological stations of the regional study area (Lamia, Aliartos, Atalanti, Theologos and Makrykapa) providing rainfall, temperature and relative humidity data. As illustrated in Fig.7, the Doorenbos Pruitt method overestimates the evapotranspiration results as opposed to the Hargreaves method, since the latter shows clearly more reliable results in daily temperature data. The Thornthwaite method also underestimates the evapotranspiration values during the winter 
months and overestimates them during the summer. The other applied methods give approximately the same results except for the Blaney - Criddle one fluctuating more smoothly throughout the year. It is also shown that there is non-unique relationship between evapotranspiration and temperature. In particular, the variation of evapotranspiration with temperature exhibits the characteristic image of a loop.

Table 3: Mean monthly (1981 - 2014) potential evapotranspiration in area's meteorological stations

\begin{tabular}{|c|c|c|c|c|c|c|c|c|c|c|c|c|c|}
\hline $\begin{array}{l}\text { Potential } \\
\text { Evapotranspir } \\
\text { ation Methods }\end{array}$ & $\begin{array}{c}\mathbf{J A} \\
\mathbf{N}\end{array}$ & $\begin{array}{c}\text { FE } \\
\text { B }\end{array}$ & $\begin{array}{c}\text { MA } \\
\mathbf{R}\end{array}$ & $\begin{array}{c}\mathbf{A P} \\
\mathbf{R}\end{array}$ & $\begin{array}{c}\text { MA } \\
\mathbf{Y}\end{array}$ & $\begin{array}{c}\mathbf{J U} \\
\mathbf{N}\end{array}$ & $\begin{array}{c}\mathbf{J U} \\
\mathbf{L}\end{array}$ & $\begin{array}{c}\mathbf{A U} \\
\mathbf{G}\end{array}$ & $\begin{array}{c}\text { SE } \\
\mathbf{P}\end{array}$ & $\begin{array}{c}\text { OC } \\
\text { T }\end{array}$ & $\begin{array}{c}\text { NO } \\
\text { V }\end{array}$ & $\begin{array}{c}\text { DE } \\
\mathrm{C}\end{array}$ & SUM \\
\hline $\begin{array}{l}\text { Penman - } \\
\text { Montieth }\end{array}$ & $\begin{array}{c}24 . \\
2\end{array}$ & $\begin{array}{c}32 . \\
1\end{array}$ & 56.7 & 89.1 & $\begin{array}{c}132 . \\
6\end{array}$ & $\begin{array}{c}171 . \\
3\end{array}$ & $\begin{array}{c}184 . \\
9\end{array}$ & $\begin{array}{c}161 . \\
5\end{array}$ & $\begin{array}{c}109 . \\
6\end{array}$ & 61.1 & 30.5 & 22.4 & $\begin{array}{r}1076 \\
.1\end{array}$ \\
\hline Thornthwaite & $\begin{array}{c}14 . \\
1\end{array}$ & $\begin{array}{c}14 . \\
9\end{array}$ & 27.9 & 54.3 & 99.9 & $\begin{array}{c}151 . \\
9\end{array}$ & $\begin{array}{c}177 . \\
2\end{array}$ & $\begin{array}{c}159 . \\
9\end{array}$ & $\begin{array}{c}112 . \\
2\end{array}$ & 67.3 & 32.5 & 19.0 & $\begin{array}{r}931 . \\
1\end{array}$ \\
\hline $\begin{array}{l}\text { Blaney - } \\
\text { Criddle }\end{array}$ & $\begin{array}{c}65 . \\
1\end{array}$ & $\begin{array}{c}64 . \\
5\end{array}$ & 86.3 & $\begin{array}{c}106 . \\
3\end{array}$ & $\begin{array}{c}135 . \\
5\end{array}$ & $\begin{array}{c}154 . \\
8\end{array}$ & $\begin{array}{c}164 . \\
9\end{array}$ & $\begin{array}{c}152 . \\
7\end{array}$ & $\begin{array}{c}124 . \\
6\end{array}$ & $\begin{array}{c}101 . \\
9\end{array}$ & 76.4 & 67.0 & $\begin{array}{r}1300 \\
.1\end{array}$ \\
\hline Hargreaves & $\begin{array}{c}27 . \\
9\end{array}$ & $\begin{array}{c}34 . \\
6\end{array}$ & 58.1 & 76.5 & 99.6 & $\begin{array}{c}101 . \\
3\end{array}$ & $\begin{array}{c}109 . \\
1\end{array}$ & 95.2 & 90.5 & 66.0 & 35.8 & 32.0 & $\begin{array}{r}826 . \\
4\end{array}$ \\
\hline Doorenbos - & 49. & 59. & & 138. & 193. & 241. & 256. & 227. & $\begin{array}{c}162 . \\
5\end{array}$ & 100. & & & $\begin{array}{r}1623 \\
4\end{array}$ \\
\hline $\begin{array}{l}\text { Pruitt } \\
\text { Priestley - }\end{array}$ & 5 & $\begin{array}{c}3 \\
23 .\end{array}$ & 93.7 & 0 & $\begin{array}{c}6 \\
141 .\end{array}$ & $\begin{array}{c}1 \\
175 .\end{array}$ & $\begin{array}{c}5 \\
187 .\end{array}$ & $\begin{array}{c}3 \\
159 .\end{array}$ & 5 & 3 & 7.1 & 44.4 & $\begin{array}{r}.4 \\
1008\end{array}$ \\
\hline Taylor & 9.2 & 6 & 54.2 & 92.9 & 2 & 2 & 3 & 4 & 98.8 & 47.2 & 13.9 & 4.9 & .0 \\
\hline
\end{tabular}
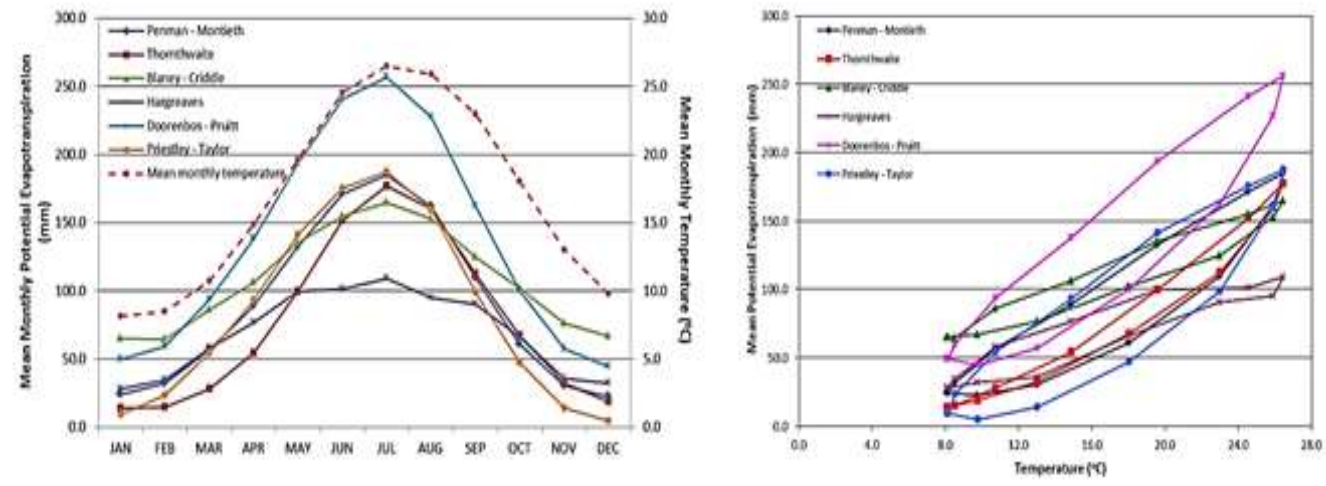

Fig.7: Potential evapotranspiration mean monthly $(1981$ - 2014) variation (left) and the evapotranspiration as a function of temperature (right).

So, if having the same temperature in an autumn and spring month, the evaporation for the first is significantly less than it is for the second. This is explained by the fact that despite the same temperature, solar radiation in the autumn month is lower than in the spring. Conversely, for the same value of solar radiation higher temperature appears in autumn than in spring. This is explained by the thermal earth inertia resulttvy in the temperature change not just following the solar radiation but lagging behind time ${ }^{36}$. 


\section{Actual Evapotranspitation}

(A) Turc ${ }^{29}$ : this method is based on the precipitation and the thermal indices given by the following equation:

$$
E T_{r}=\frac{P}{\sqrt{0.9+(P / L T)^{2}}}
$$

where,

$\boldsymbol{E} \boldsymbol{T}_{\boldsymbol{a}}=$ the mean overannual actual evapotranspiration $(\mathrm{mm}) ; \boldsymbol{P}=$ the mean overannual rainfall $(\mathrm{mm})$ and

$$
L_{T}=300+25 T+0.05 T^{3}
$$

where,

$\boldsymbol{T}=$ the mean overannual temperature $\left({ }^{0} \mathrm{C}\right)$. Also, the assumption that $P / L T>0.316$ has to be applied.

Turc corrected ${ }^{29-31}$ : in order the temperature to be more accurately estimated the corrected value of is used given by the equation:

$$
T_{\Delta}=\sum_{l}^{12} P_{i} T_{i} / \sum_{l}^{12} P_{i}
$$

where,

$\boldsymbol{P}_{i}=$ the mean monthly precipitation in $\mathrm{mm} ; \boldsymbol{T}_{i}=$ the mean monthly temperature in ${ }^{0} \mathrm{C}$ and

$$
\boldsymbol{P}=\text { the mean overannual precipitation. }
$$

(B) Santoro: Santoro ${ }^{32}$ by studying 192 basins in Sicily with mean annual temperatures ranging between $10^{\circ} \mathrm{C}$ and $18^{\circ} \mathrm{C}$, suggested the following equation for $L_{T}$ estimation:

$$
L_{T}=586-10 T+0.05 T^{3}
$$

The other parameters remain the same with those in Turc method and the corrected value of $T_{M}$ instead of the mean annual temperature is used.

(C) Coutagne ${ }^{33}$ : this method is same as Turc given by the following equation:

$$
E T_{a}=P-P^{2} / \lambda \text {, since } \lambda / 8 \leq P \leq \lambda / 2
$$

where,

$\boldsymbol{E} \boldsymbol{T}_{r}=$ the mean overannual evapotranspiration $(\mathrm{mm})$

$\boldsymbol{P}=$ the mean overannual precipitation $(\mathrm{mm})$ and

$$
\lambda=800+140 T
$$

where, 
$\boldsymbol{T}=$ the mean overannual temperature $\left({ }^{0} \mathrm{C}\right)$.

If the rainfall amount is less than $\lambda / 8$, then the evapotranspiration is equal to the rainfall, while if the rainfall amount is more than $\lambda / 2$, then the evapotranspiration is precipitation independent given by the equation:

$$
E T_{a}=200+35 T .
$$

(D) Burdon - Papakis ${ }^{34}$ : in this method $E T_{a}$ is given by the following algorithm:

$$
\text { If } P>1000 \mathrm{~mm} \text { then } E T_{a}=P-\left[500 \mathrm{~mm}_{(\mathrm{NOV}-M A R]}+P_{(A P R-O C T)}\right]
$$$$
\text { If } 1000>P>250 \mathrm{~mm} \text { then } E T_{a}=P-\left[0.5 P_{(N O V-M A R)}+P_{(A P R-O C T)}\right)
$$

If $P<250 \mathrm{~mm}$ then $E T_{a}=P$

where,

$\boldsymbol{P}=$ the overall mean overannual precipitation; $\boldsymbol{P}_{(\mathbf{N O V}-\mathbf{M A R})}=$ the overall mean precipitation between November and March; $\boldsymbol{P}_{(\text {APR-OCT })}=$ the overall mean precipitation between April and October and

$\boldsymbol{E} \boldsymbol{T}_{\boldsymbol{a}}=$ the mean annual actual evapotranspiration. However, it has to be mentioned that this method provides reliable and accurate results within karstic aquifers and not within porous ones.

(E) Thornthwaite - Mather ${ }^{4}$ : assumes that soil-moisture-retained water is a storage added to rainfall and due to the evapotranspiration process this storage decreases over time. Many parameters are calculated for estimating the water balance, such as the mean monthly precipitation, the mean monthly evapotranspiration, the difference in the amount of rain - evapotranspiration, the aggregated potential water loss, the retention capacity and the storage variations, the actual evapotranspiration, the moisture deficit and the moisture excess.

The aggregated potential water loss equals to zero in the case of $P \geq E T_{p}$ and when $P<E T_{p}$, then the value is equal to the sum of the difference $P-E T_{p}$ of a specific month and the values of the aggregated potential water loss of the previous month, that is, A.P.W.L.m $=\left(P-E T_{p}\right)_{\mathrm{m}}+A . P . W . L \cdot \mathrm{m}-1$. The retention capacity depends on the soil nature and the vegetation, so its value may vary by location in the area. The values of maximum retention capacity adopted in this paper are in the order of $130 \mathrm{~mm}$. The actual evapotranspiration equals to the potential one, if $P-E T_{p} \geq 0$. Otherwise, the actual evapotranspiration equals to the sum of the rainfall amount and the absolute value of the change in soil moisture content $|\Delta \mathrm{St}|$. When the actual evapotranspiration equals to the potential there is no moisture deficit $(D=0)$. When $E T_{p}>E T_{a}$, then the moisture deficit equals to their difference, that is, $D=E T_{p}-E T_{a}$. Finally, when the rainfall amount is less than the potential evapotranspiration, then there is no moisture excess. Otherwise, the moisture excess equals to the difference in the rainfall amount from the potential evapotranspiration and the absolute value of the change in soil moisture, that is, $S=P-E T_{p}-|\Delta S t|$. After determining the actual evapotranspiration for each of the stations in the regional study area, the water balance was computed, concluding that there is a water deficit from May to September. The replenishment of soil moisture begins in October and ends in December, with a water surplus appearing in the months of January to March (Fig.8). Climatic parameters, such as rain and temperature, vary linearly with altitude and a similar linear relationship for evaporation is also expected. 


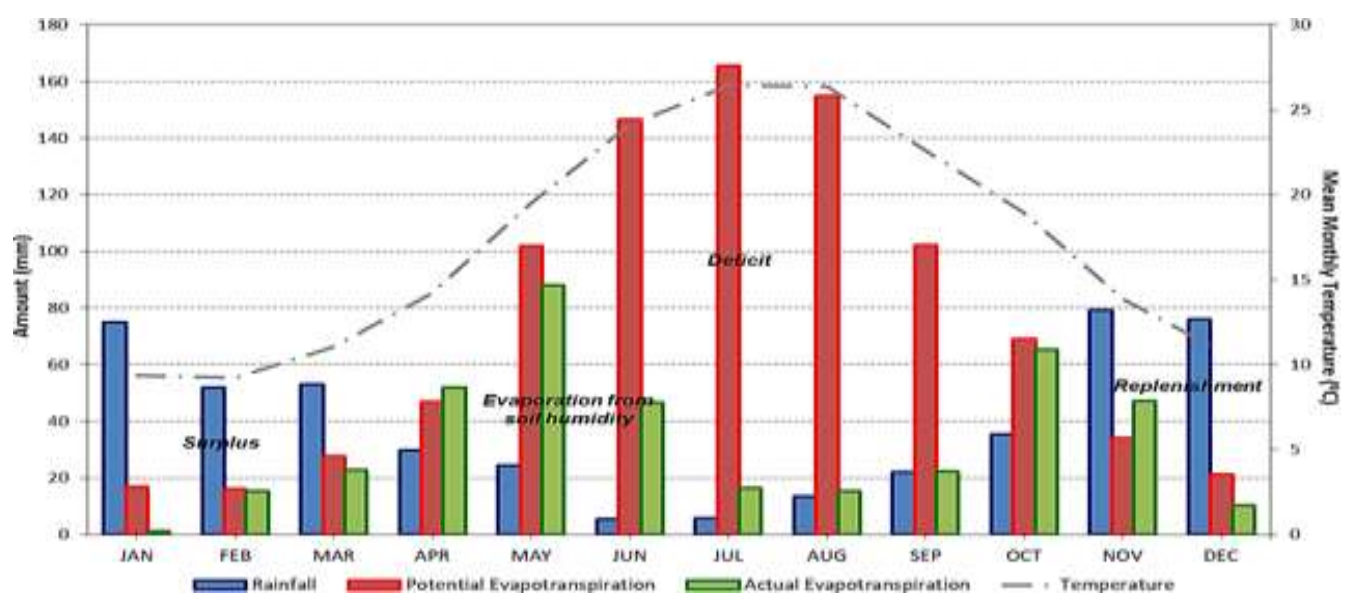

Fig.8: Graphical presentation of the mean overannual precipitation and temperature in relation with the mean annual potential and actual evapotranspiration according to Thornthwaite - Mather method for the Atalanti river basin.

It is observed that the linear relationship between evapotranspiration and altitude has a fairly good correlation coefficient $\left(R^{2}=0.67\right)$. For the study area, the equation $E T_{a}=0.12 Z+439.6$ is applied based on the Thornthwaite - Mather evapotranspiration method, which was eventually adopted as the most appropriate for the research area data. According to this relation, the actual evapotranspiration is increased by $12 \mathrm{~mm}$ every $100 \mathrm{~m}$ of altitude while its value at sea level is $439.6 \mathrm{~mm}$ (Fig.9). By applying the evapotranspiration variation equation with the altitude in the digital terrain model (DEM) of the Atalanti river basin, the actual evapotranspiration distribution map for the research area was constructed (Fig.10). Using this map, the mean annual evapotranspiration and the equivalent volume of water (in $\mathrm{mm}$ ) were calculated for both the geological formations and the sub-watersheds of the Atalanti river basin (Tables 4, 5 \& 6). The average annual water loss due to evapotranspiration is estimated to be $130.39 \times 10^{6} \mathrm{~m}^{3}$ which corresponds, on average, to $73.2 \%$ of the rain amount, according to this method.

Table 4: Mean annual (1981 - 2014) actual evapotranspiration $\left(\mathrm{ET}_{\mathrm{a}}\right)$ for the regional area's meteorological stations and percentage (italics) on the mean overannual rainfall.

\begin{tabular}{llllll}
\hline $\begin{array}{l}\text { Actual Evapotranspiration } \\
\text { Methods }\end{array}$ & ALIARTOS & LAMIA & ATALANTI & THEOLOGOS & MAKRYKAPA \\
\hline Turc & $506.0(88.0)$ & $\begin{array}{l}505.3 \\
(88.4)\end{array}$ & $506.0(91.2)$ & $556.9(83.0)$ & $741.9(71.4)$ \\
Turc (corrected) & $469.4(79.1)$ & $\begin{array}{l}470.3 \\
(82.2)\end{array}$ & $469.4(84.6)$ & $511.8(76.3)$ & $632.5(60.9)$ \\
Santoro & $443.6(76.0)$ & $\begin{array}{l}(76.8) \\
\text { Coutagne }\end{array}$ & $443.6(80.0)$ & $470.5(70.1)$ & $578.1(55.7)$ \\
Burdon - Papakis & $460.3(81.1)$ & $(81.5)$ & $460.3(83.0)$ & $522.8(77.9)$ & $707.4(68.1)$ \\
\multirow{2}{*}{ Thornthwaite - Mather } & $218.5(39.5)$ & $\begin{array}{l}(35.7) \\
449.1\end{array}$ & $218.5(39.4)$ & $251.5(37.5)$ & $357.7(34.4)$ \\
\hline
\end{tabular}



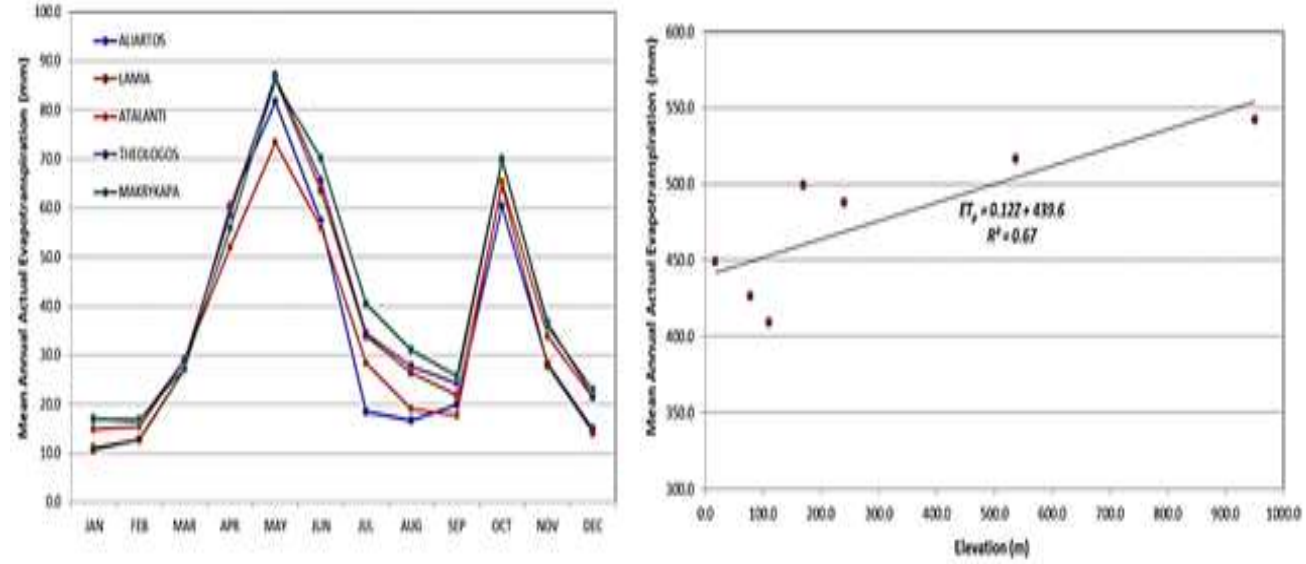

Fig.9: Mean monthly $(1981-2014)$ variation of the actual evapotranspiration $\left(E T_{a}\right)$ based on Thornthwaite - Mather method (left) and correlation of the mean overannual actual evapotranspiration with altitude (right).
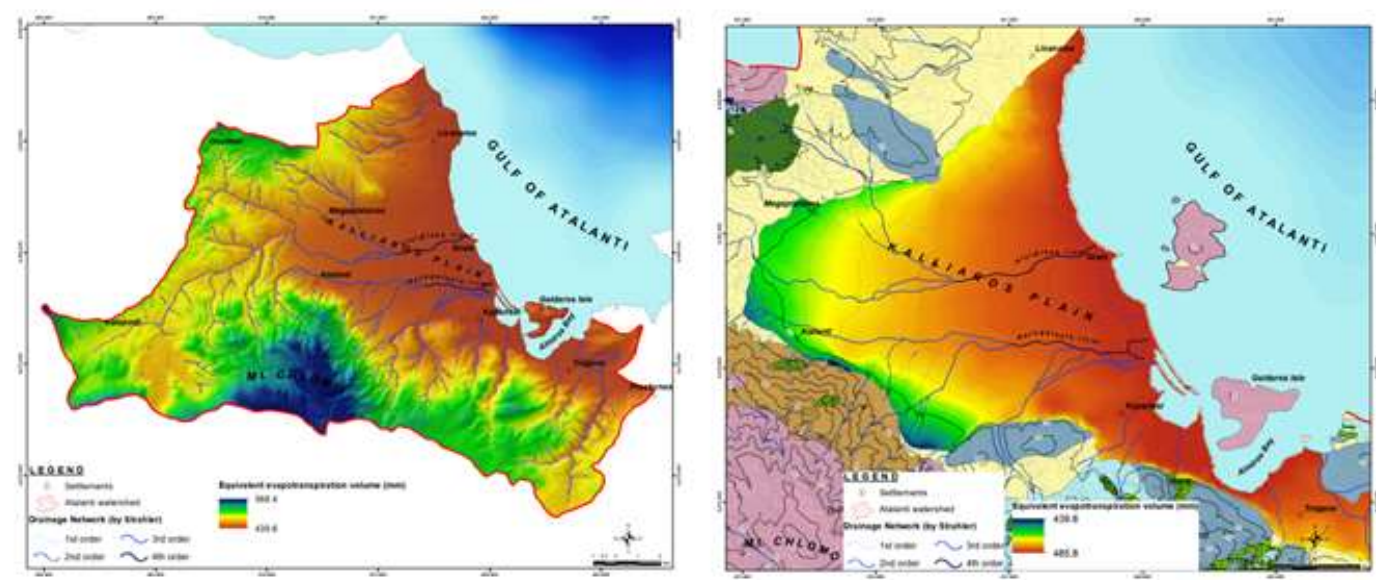

Fig.10: Mean annual (1981 - 2014) actual evapotranspiration spatial distribution in mm both in Atalanti river basin (left) and in alluvial deposits (right).

Table 5: Mean annual actual evapotranspiration (1981 - 2014) equivalent volume in $\mathrm{mm}$ for the area's sub-basins

\begin{tabular}{|c|c|c|c|c|c|c|}
\hline \multirow[b]{2}{*}{ Basin } & \multirow[b]{2}{*}{$\begin{array}{c}\text { Area } \\
\left(\times \mathbf{1 0}^{6} \mathrm{~m}^{2}\right)\end{array}$} & \multirow{2}{*}{$\begin{array}{c}\text { Mean } \\
\text { Precipitation } \\
(\mathbf{m m})\end{array}$} & \multicolumn{3}{|c|}{ Evapotranspiration } & \multirow[b]{2}{*}{$\begin{array}{c}\text { Evapotranspiration } \\
\text { volume }\left(\times 10^{6} \mathrm{~m}^{3}\right)\end{array}$} \\
\hline & & & $\begin{array}{l}\text { Minimum } \\
(\mathbf{m m})\end{array}$ & $\begin{array}{c}\text { Maximum } \\
(\mathbf{m m})\end{array}$ & $\begin{array}{l}\text { Mean } \\
(\mathrm{mm})\end{array}$ & \\
\hline Alarginos & 109.1 & 688.9 & 439.6 & 566.8 & 476.9 & 57.79 \\
\hline Karagkiozis & 55.2 & 695.7 & 439.6 & 568.4 & 477.0 & 29.24 \\
\hline $\begin{array}{l}\text { Agios } \\
\text { Ioannis }\end{array}$ & 55.4 & 637.1 & 439.6 & 551.2 & 469.8 & 26.03 \\
\hline Others & 29.8 & 669.1 & 439.6 & 539.8 & 508.9 & 17.33 \\
\hline$S U M$ & 249.5 & & & & & 130.39 \\
\hline
\end{tabular}


Table 6: Mean annual actual evapotranspiration (1981 - 2014) equivalent volume in mm per geological formation

\begin{tabular}{lccccc}
\hline $\begin{array}{l}\text { Geological } \\
\text { Formation }\end{array}$ & $\begin{array}{c}\text { Area } \\
\left(\times \mathbf{1 0}^{\mathbf{6}} \mathbf{m}^{\mathbf{2}}\right)\end{array}$ & $\begin{array}{c}\text { Precipitation } \\
\text { volume } \\
\left(\times \mathbf{1 0}^{\mathbf{6}} \mathbf{m}^{\mathbf{3}}\right)\end{array}$ & $\begin{array}{c}\text { Evapotranspiration } \\
\text { volume }\left(\times \mathbf{1 0}^{\mathbf{6}} \mathbf{m}^{\mathbf{3}}\right)\end{array}$ & $\begin{array}{c}\text { Evapotranspiration } \\
\text { percent }(\boldsymbol{\%})\end{array}$ & $\begin{array}{c}\text { Evapotranspiration } \\
\text { equivalent in } \mathbf{m m}\end{array}$ \\
\hline Alluvial deposits & 58.7 & 29.01 & 23.76 & 81.90 & 419.6 \\
Bauxites - Fe-Ni ore & 0.06 & 0.05 & 0.044 & 88.9 & 733.3 \\
Neogene deposits & 72.4 & 51.03 & 39.25 & 76.9 & 542.1 \\
Carbonate rocks & 71.9 & 62.22 & 39.53 & 63.5 & 549.8 \\
Conglomerates & 0.3 & 0.22 & 0.105 & 47.7 & 350.0 \\
Schists-Keratolithes- & 2.0 & 1.39 & 1.05 & 75.5 & 525.0 \\
Phyllites & 0.03 & 0.02 & 0.015 & 75.0 & 500.0 \\
Flysch & 11.7 & 9.54 & 7.69 & 80.6 & 657.3 \\
Graouvakes - & & & 18.94 & 76.7 & 584.6 \\
Quartzites - Tuffs & 32.4 & 24.69 & $\mathbf{1 3 0 . 3 9}$ & $\mathbf{1 0 0 . 0}$ & \\
Basic- Ultrabasic & $\mathbf{1 7 8 . 1 7}$ & & & \\
rocks & $\mathbf{S U M}$ & & & &
\end{tabular}

Infiltration: Another key component in the water balance calculation is the infiltration, that is, the meteoric water that infiltrates through the rocks recharging aquifers. This parameter plays a significant role for determining a region's hydro-economy because it contributes to replenishing groundwater reservoirs ${ }^{23}$. The infiltration represents the part of atmospheric precipitation and surface runoff which flows vertically, due to gravity, to the subsoil and reaches the aquifers added to the groundwater reservoirs. In other words, the water amount that infiltrates, in the first place, replenishes the soil moisture deficit, while that of effective infiltration flows deeper recharging the groundwater aquifers. The infiltration capacity depends on soil moisture, lithology, soil slope, vegetation, rainfall intensity and distribution, etc. The infiltration coefficient expresses is the meteoric water that infiltrates in relation to the total rainfall. Estimates and measurements from other areas of Greek territory, based on references, were used to estimate the infiltration rate of the geological formations found in the research area. In Tables $7 \& \mathbf{8}$, the infiltration coefficients adopted for the area's geological formations are summarized, as well as the equivalent infiltration volume in $\mathrm{mm}$, calculated for each pixel separately if the rain gradient and the infiltration coefficient are known. The calculations (Fig.11) show that the mean annual infiltration volume is $38.03 \times 10^{6} \mathrm{~m}^{3}$, which corresponds to an average of $21.3 \%$ of the rainfall over the entire Atalanti river basin ${ }^{37}$.

Table 7: Mean annual (1981 - 2014) infiltration equivalent volume in mm for the area'a sub-basins

\begin{tabular}{|c|c|c|c|c|c|c|}
\hline \multirow[b]{2}{*}{ Basin } & \multirow{2}{*}{$\begin{array}{c}\text { Area } \\
\left(\times 10^{6} \mathrm{~m}^{2}\right)\end{array}$} & \multirow{2}{*}{$\begin{array}{c}\text { Mean } \\
\text { Precipitation } \\
(\mathrm{mm})\end{array}$} & \multicolumn{3}{|c|}{ Infiltration } & \multirow{2}{*}{$\begin{array}{c}\text { Infiltration } \\
\text { volume }\left(\times 10^{6} \mathrm{~m}^{3}\right)\end{array}$} \\
\hline & & & $\begin{array}{c}\text { Minimum } \\
(\mathrm{mm})\end{array}$ & $\begin{array}{c}\text { Maximum } \\
(\mathbf{m m})\end{array}$ & $\begin{array}{l}\text { Mean } \\
(\mathrm{mm})\end{array}$ & \\
\hline Alarginos & 109.1 & 688.9 & 64.8 & 187.8 & 112.5 & 17.82 \\
\hline Karagkiozis & 55.2 & 695.7 & 64.8 & 208.4 & 114.6 & 9.09 \\
\hline $\begin{array}{l}\text { Agios } \\
\text { Ioannis }\end{array}$ & 55.4 & 637.1 & 64.8 & 142.9 & 98.7 & 5.47 \\
\hline Others & 29.8 & 669.1 & 66.2 & 136.8 & 87.3 & 5.65 \\
\hline SUM & 249.5 & & & & & 38.03 \\
\hline
\end{tabular}


Table 8: Mean annual (1981 - 2014) infiltration equivalent volume in mm per geological formation.

\begin{tabular}{lccccc}
\hline Geological Formation & $\begin{array}{c}\text { Area } \\
\left(\times \mathbf{1 0}^{\mathbf{6}} \mathbf{m}^{\mathbf{2}}\right)\end{array}$ & $\begin{array}{c}\text { Precipitation } \\
\mathbf{v o l u m e} \\
\left(\times \mathbf{1 0}^{\mathbf{6}} \mathbf{m}^{\mathbf{3}}\right)\end{array}$ & $\begin{array}{c}\text { Infiltration } \\
\mathbf{c o e f f i c i e n t} \\
(\mathbf{\%})\end{array}$ & $\begin{array}{c}\text { Infiltration } \\
\text { volume } \\
\left(\times \mathbf{1 0}^{\mathbf{6}} \mathbf{m}^{\mathbf{3}}\right)\end{array}$ & $\begin{array}{c}\text { Infiltration } \\
\text { equivalent in } \\
\mathbf{m m}\end{array}$ \\
\hline Alluvial deposits & 58.7 & 29.01 & 14 & 4.06 & 69.2 \\
Bauxites - Fe-Ni ore & 0.06 & 0.05 & 2 & 0.001 & 16.7 \\
Neogene deposits & 72.4 & 51.03 & 8 & 4.08 & 56.4 \\
Carbonate rocks & 71.9 & 62.22 & 44 & 28.00 & 389.4 \\
Conglomerates & 0.3 & 0.22 & 21 & 0.048 & 160.0 \\
Schists-Keratolithes-Phyllites & 2.0 & 1.39 & 3 & 0.042 & 21.0 \\
Flysch & 0.03 & 0.02 & 4 & 0.001 & 33.3 \\
Graouvakes - Quartzites - & 11.7 & 9.54 & 2 & 0.19 & 16.2 \\
Tuffs & 32.4 & 24.69 & 2 & 0.74 & 22.8 \\
Basic- Ultrabasic rocks & $\mathbf{2 4 9 . 5}$ & $\mathbf{1 7 8 . 1 7}$ & & $\mathbf{3 8 . 0 3}$ & \\
SUM & & & & & \\
\hline
\end{tabular}
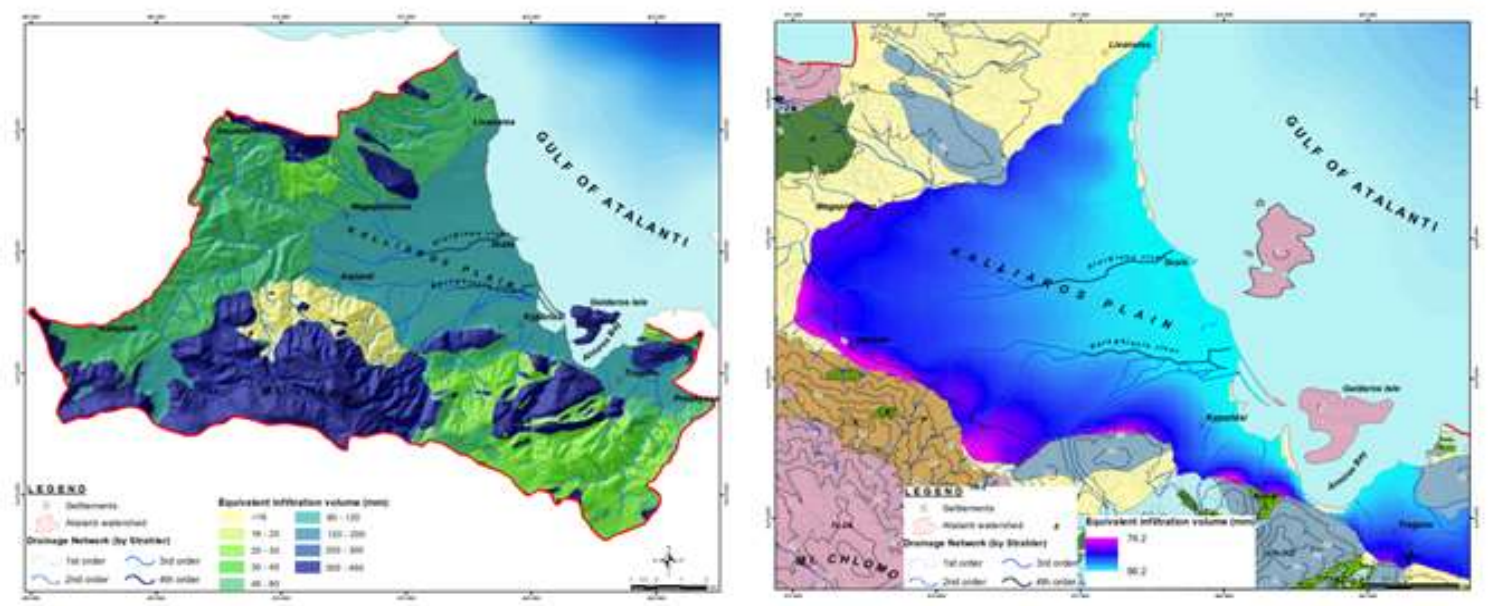

Fig.11: Mean annual (1981 - 2014) infiltration spatial distribution in mm both in Atalanti river basin (left) and in alluvial deposits (right).

Surface Runoff: The total surface runoff $\left(Q_{t}\right)$ is the sum of the direct runoff (the percentage of rainfall that, after reaching the surface, is channeled through the drainage network to surface water bodies), the subsurface flow, which after a short time ends in the drainage and of the basic flow. The main factors affecting the surface runoff are climatic (rainfall intensity, air humidity, winds, evaporation), geomorphological (catchment slope, drainage density), lithological (rock type, permeability) as well as vegetation cover. The total runoff can be determined by using catchment simulation models, "rainfall-discharge" mathematical models and approximate water balance if all the other parameters are already known or directly with measurements at the output of each sub-basin.

In the study area no runoff measurements have been made at the outlet of the sub-basins, therefore it was considered appropriate to indirectly estimate the surface runoff through the water balance for both the sub-basins and the geological formations (Tables $9 \& \mathbf{1 0}$ ). The calculations show that the mean annual surface runoff volume is $9.75 \times 10^{6} \mathrm{~m}^{3}$, which corresponds, on average, to $5.5 \%$ of the rainfall over the entire river basin (Fig.11). 
Table 9: Mean annual (1981 - 2014) surface runoff equivalent volume in mm for the area'a subbasins.

\begin{tabular}{lccccc}
\hline Basin & $\begin{array}{c}\text { Area } \\
\left(\times \mathbf{1 0}^{\mathbf{6}} \mathbf{m}^{\mathbf{2}}\right)\end{array}$ & $\begin{array}{c}\text { Mean } \\
\text { Precipitation } \\
(\mathbf{m m})\end{array}$ & $\begin{array}{c}\text { Mean Surface } \\
\text { Runoff }(\mathbf{m m})\end{array}$ & $\begin{array}{c}\text { Surface Runoff } \\
\text { volume }\left(\times \mathbf{1 0}^{\mathbf{6}} \mathbf{m}^{\mathbf{3}}\right)\end{array}$ & $\begin{array}{c}\text { Percent } \\
(\boldsymbol{\%})\end{array}$ \\
\hline Alarginos & 109.1 & 688.9 & 41.1 & 4.48 & 6.0 \\
Karagkiozis & 55.2 & 695.7 & 40.9 & 2.26 & 5.9 \\
Agios Ioannis & 55.4 & 637.1 & 39.4 & 2.18 & 6.2 \\
Others & 29.8 & 669.1 & 35.3 & 0.83 & 5.3 \\
SUM & $\mathbf{2 4 9 . 5}$ & & & $\mathbf{9 . 7 5}$ & \\
\hline
\end{tabular}

Table 10: Mean annual surface runoff $(1981$ - 2014) equivalent volume in mm per geological formation.

\begin{tabular}{lcccc}
\hline Geological Formation & $\begin{array}{c}\text { Area } \\
\left(\times \mathbf{1 0}^{\mathbf{6}} \mathbf{m}^{\mathbf{2}}\right)\end{array}$ & $\begin{array}{c}\text { Precipitation } \\
\mathbf{v o l u m e} \\
\left(\times \mathbf{1 0}^{\mathbf{6}} \mathbf{m}^{\mathbf{3}}\right)\end{array}$ & $\begin{array}{c}\text { Surface } \\
\text { Runoff } \\
\mathbf{v o l u m e} \\
\left(\times \mathbf{1 0}^{\mathbf{6}} \mathbf{m}^{\mathbf{3}}\right)\end{array}$ & $\begin{array}{c}\text { Surface Runoff } \\
\text { equivalent in } \mathbf{~ m m}\end{array}$ \\
\hline Alluvial deposits & 58.7 & 29.01 & 0.317 & 5.4 \\
Bauxites - Fe-Ni ore & 0.06 & 0.05 & 0.0016 & 26.8 \\
Neogene deposits & 72.4 & 51.03 & 2.592 & 35.8 \\
Carbonate rocks & 71.9 & 62.22 & 3.233 & 45.0 \\
Conglomerates & 0.3 & 0.22 & 0.062 & 206.8 \\
Schists-Keratolithes-Phyllites & 2.0 & 1.39 & 0.325 & 162.3 \\
Flysch & 0.03 & 0.02 & 0.0069 & 231.1 \\
Graouvakes - Quartzites - Tuffs & 11.7 & 9.54 & 0.679 & 58.1 \\
Basic - Ultrabasic rocks & 32.4 & 24.69 & 2.534 & 78.2 \\
SUM & $\mathbf{2 4 9 . 5}$ & $\mathbf{1 7 8 . 1 7}$ & $\mathbf{9 . 7 5}$ & \\
\hline
\end{tabular}

\subsection{Overall Water Balance Quantitative:}

Assessment and Results' Analysis: Based on the above calculations of precipitation, evapotranspiration, surface runoff and infiltration and according to the simplified water balance equation, an approximate hydrological balance was estimated. The quantification of the water balance parameters results in significant differences and sometimes convergences in the final results, because each method uses less or more parameters as well as the assumptions of the different methods may differ significantly from each other. Based on the calculations and estimates for each of the water balance components, the overall sub-basins' water balance (Tables 11 \& 12) was derived. It results that the mean rainfall throughout the catchment is about $714.1 \mathrm{~mm}$ or $178.17 \times 10^{6} \mathrm{~m}^{3}$, of which $130.39 \times 10^{6} \mathrm{~m}^{3}$ or $522.6 \mathrm{~mm}(73.2 \%)$ relate to the actual evapotranspiration, $9.75 \times 10^{6} \mathrm{~m}^{3}$ or $39.1 \mathrm{~mm}$ $(5.5 \%)$ correspond to surface runoff, while $38.03 \times 10^{6} \mathrm{~m}^{3}$ or $152.4 \mathrm{~mm}(21.3 \%)$ enrich groundwater recharging the aquifers. 
Table 11: Water balance parameters' calculation for the area's sub-basins.

\begin{tabular}{lccccc}
\hline Basin & $\begin{array}{c}\text { Area } \\
\left(\times \mathbf{1 0}^{\mathbf{6}} \mathbf{m}^{\mathbf{2}}\right)\end{array}$ & $\begin{array}{c}\text { Mean } \\
\text { Precipitation } \\
(\mathbf{m m})\end{array}$ & $\begin{array}{c}\text { Mean } \\
\text { Evapotranspiration } \\
(\mathbf{m m})\end{array}$ & $\begin{array}{c}\text { Mean Surface } \\
\text { Runoff }(\mathbf{m m})\end{array}$ & $\begin{array}{c}\text { Mean } \\
\text { Infiltration } \\
(\mathbf{m m})\end{array}$ \\
\hline Alarginos & 109.1 & 688.9 & 476.9 & 41.5 & 112.5 \\
Karagkiozis & 55.2 & 695.7 & 477.2 & 40.9 & 114.6 \\
Agios Ioannis & 55.4 & 637.1 & 469.8 & 39.6 & 98.7 \\
Others & 29.8 & 669.1 & 508.9 & 35.6 & 87.6 \\
$\boldsymbol{S U M}$ & $\mathbf{2 4 9 . 5}$ & & & & \\
\hline
\end{tabular}

Table 12: Water balance parameters' calculation with percentages per geological formation.

\begin{tabular}{|c|c|c|c|c|c|}
\hline $\begin{array}{l}\text { Geological } \\
\text { Formation }\end{array}$ & $\begin{array}{c}\text { Area } \\
\left(\times 10^{6} \mathrm{~m}^{2}\right)\end{array}$ & $\begin{array}{c}\text { Mean } \\
\text { Precipitation } \\
\text { (mm) }\end{array}$ & $\begin{array}{c}\text { Mean } \\
\text { Evapotranspiration } \\
(\mathbf{m m})\end{array}$ & $\begin{array}{c}\text { Mean } \\
\text { Surface } \\
\text { Runoff } \\
\text { (mm) }\end{array}$ & $\begin{array}{c}\text { Mean } \\
\text { Infiltration } \\
(\mathbf{m m})\end{array}$ \\
\hline Alluvial deposits & 58.7 & 494.2 & 419.6 & 5.4 & 69.2 \\
\hline Bauxites - Fe-Ni ore & 0.06 & 776.8 & 733.3 & 26.8 & 16.7 \\
\hline Neogene deposits & 72.4 & 634.3 & 542.1 & 35.8 & 56.4 \\
\hline Carbonate rocks & 71.9 & 800.1 & 549.8 & 45.0 & 389.3 \\
\hline Conglomerates & 0.3 & 716.8 & 350.0 & 206.8 & 160.0 \\
\hline $\begin{array}{l}\text { Schists-Keratolithes- } \\
\text { Phyllites }\end{array}$ & 2.0 & 708.3 & 525.0 & 162.3 & 21.0 \\
\hline Flysch & 0.03 & 764.4 & 500.0 & 231.1 & 33.3 \\
\hline $\begin{array}{l}\text { Graouvakes - } \\
\text { Quartzites - Tuffs }\end{array}$ & 11.7 & 731.6 & 657.3 & 58.1 & 16.2 \\
\hline $\begin{array}{l}\text { Basic - Ultrabasic } \\
\text { rocks }\end{array}$ & 32.4 & 685.6 & 584.6 & 78.2 & 22.8 \\
\hline$S U M$ & 249.5 & & & & \\
\hline
\end{tabular}

3.3. Water Needs per Use: The water needs assessment, as taken place in the present essay, is an attempt to estimate and approximate the actual water needs based on the 2011 demographic data and the River Basins Management Plans $(2013,2017)$ so as to obtain a first estimation of the region's water resources adequacy. All possible uses of ground and surface water were taken into account, however, with emphasis on the two main ones, namely, water supply and irrigation (Fig.12). 


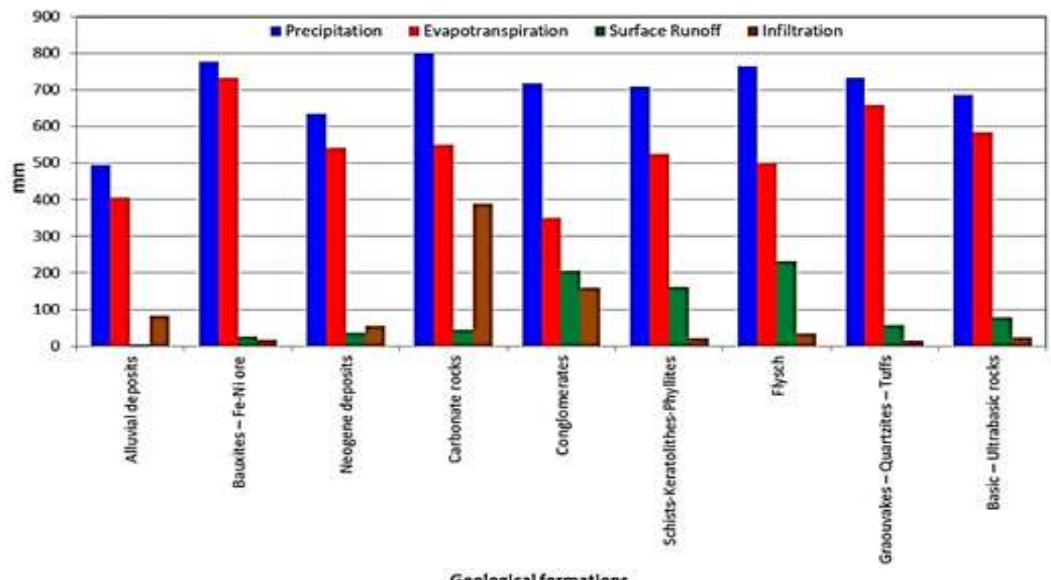

Geological formations
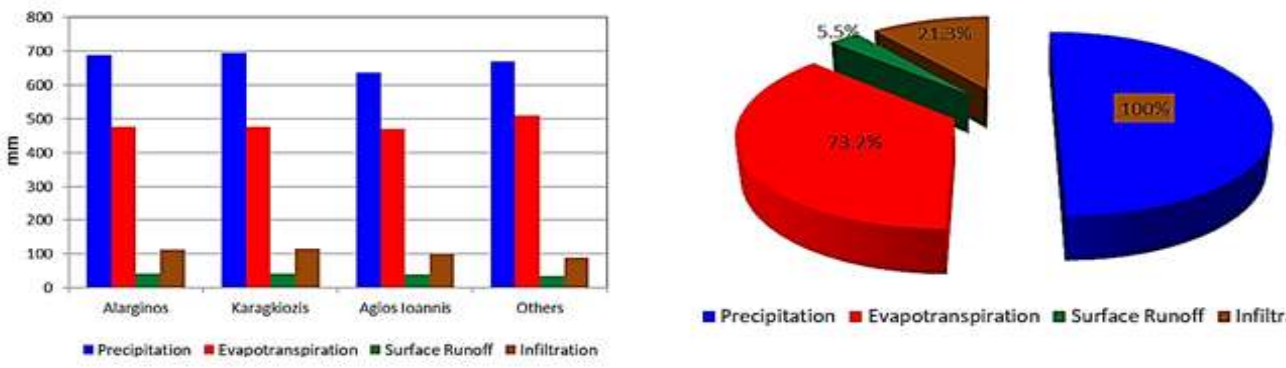

- Precipitation = Evapotranspiration $\mathbf{a}$ Surface Runoff $\mathbf{v}$ Infiltration

Fig.12: Water balance parameters in mm per geological formation (up), water balance parameters estimation in $\mathrm{mm}$ for the area's sub-basins (down left) and overall estimation of the water balance parameters for the whole basin in \% (down right) during the period $1981-2014$.

The other uses (industrial, livestock, tourism, etc.) make up a small percentage of the total water used in the research area. The Hellenic Statistical Service's population census data were used to calculate water needs per municipality, for the year 2011, according to the equation:

$$
V_{\text {sup }}=(\Pi \cdot q)+D
$$

where,

$\boldsymbol{V}_{\text {sup }}=$ the water supply needs

$\boldsymbol{\Pi}=$ the population

$\boldsymbol{Q}=$ the average per capita water consumption estimated at $2501 / \mathrm{d}$ and

$\boldsymbol{D}=$ the water supply losses estimated at about $40 \%$.

Based on the above equation the total water needs for the research area amount to $1.43 \times 10^{6} \mathrm{~m}^{3} / \mathrm{yr}$. The spatial distribution of the crop vegetation, as depicted in the CORINE Land Cover in 2012, as well as the study by the Ministry of the Environment and Energy, was used to calculate irrigation needs according to the River Basin Management Plan of Eastern - Central Greece. Each crop irrigation needs were calculated on a monthly basis according to Blaney \& Criddle method ${ }^{25}$, by using the following relationship:

$$
V_{i r r}(i)=V_{E T} p^{(i)}-V \operatorname{Pr}(i)
$$


where,

$V_{\text {irr }(i)}=$ the crop irrigation needs

$V_{E T p(i)=}$ the potential evapotranspiration volume

$V_{\boldsymbol{P r}(i)}=$ the rain water volume .

The the potential evaporation water volume per crop is given by the equation:

$$
V_{E T_{p}(i)}=E T_{p}{ }^{(i)} \cdot A_{(i)}=\left[K_{(i)} \cdot(8.13+0.46 \cdot T) \cdot P\right] \cdot A_{(i)}
$$

where,

$\boldsymbol{E} \boldsymbol{T}_{\boldsymbol{p}(i)=}$ the potential evapotranspiration in $\mathrm{mm}$

$\boldsymbol{A}_{(i)}=$ the area occupied by the crop in $\mathrm{m}^{2}$

$\boldsymbol{K}_{(i)}=$ the crop water use factor

$\boldsymbol{T}=$ the mean monthly temperature and

$\boldsymbol{P}=$ the percentage of daylight during the month as a function of latitude.

Therefore, the total irrigation needs for the research area amount to $36.4 \times 10^{6} \mathrm{~m}^{3} / \mathrm{yr}$, a multiple amount compared to the water supply needs, which proves that irrigation is the largest consumer in the regional area. It is observed that the coastal area has increased consumption needs, to which both the needs for livestock and industrial use, which amount to $95,200 \mathrm{~m} 3 / \mathrm{yr}$ and 550,000m3/yr, respectively should be added based on the $1^{\text {st }}$ Review of River Basin Management Plans of the Water District of the Eastern - Central Greece, as well as the needs arising from the increase in population due to tourism, mainly during the summer months, which however do not exceed 50,000 $\mathrm{m}^{3} / \mathrm{yr}$ (Fig.13).

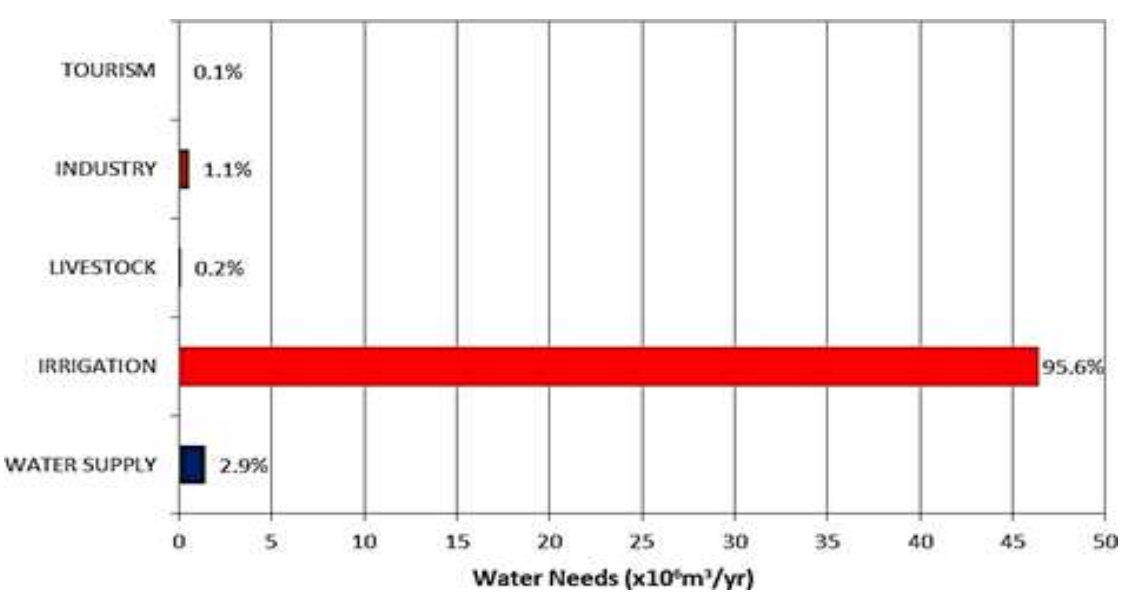

Fig.13: Water needs percentage per use

\section{CONCLUSIONS}

Under conditions where water availability is limiting, water balance calculations are essential in soilwater relationships studies. In the case study described above, the groundwater potential was carried out using water balance approach and the water budget was estimated through hydrological balance 
components' calculation. All the available data were used, namely, the precipitation and temperature dataset from the adjacent rain and meteorological stations so as to calculate as accurately as possible the water balance parameters. Also, the most well-known equations for potential and actual evapotranspiration were implemented so as to make the results comparable and choose the most appropriate for the study area. Moreover, the infiltration coefficient was assessed through literature based on the properties of each geological formation and finally, the surface runoff was indirectly computed given that the other parameters were already known. The net recharge to groundwater from different sources was quantified to determine the available groundwater potential in the area. All these water balance elements were presented and visualized in a GIS spatial distribution environment after applying regression analysis for the whole basin. Water balance results showed that water losses in the Atalanti river basin represent almost $73 \%$ of the total precipitation volume, whereas water availability is further limited if seawater intrusion and summer runoff low values are taken into account. Furthermore, the agricultural pressure in the regional area seems to be the most water consuming since irrigation uses the majority of surface and ground water (almost 96\% of total water needs). Besides, groundwater development was found under over exploited condition which is mainly caused by sustained groundwater pumping, thus, reducing excess pumping and proper utilization of rainwater using rainwater harvesting techniques are of crucial issues that have to be dealt with for a sustainable water resources assessment and management plan.

\section{ACKNOWLEDGEMENTS}

The authors would like to express their thanks to the Hellenic National Meteorological Service (HNMS) and the Ministry of Environment and Energy for the hydrometeorological stations' precipitation and temperature dataset of the regional area.

Conflict of Interests: The authors confirm that there is no conflict of interests referred to in the paper.

\section{REFERENCES}

1. M. Mimikou, Water resources in Greece: Present and Future, Global NEST Journal.2005, 7 (3), pp.313-322.

2. L. Zhang, N. Potter, K. Hickel, Y. Zhang, Q. Shao, Water balance modeling on the Budyko framework - Model development and testing, Journal of Hydrology, 2008,360, pp.117-131.

3. W. Thornthwaite, An approach towards a rational classification of climate. Geogr. Rev.1948, 38, pp.55- 94.

4. W. Thornthwaite, R. Mather, The water balance. Thornthwaite Ass. Lab., New Jersey. Climatology, 1957, 8 (1), pp.1-37.

5. K. Beven, Changing idea in hydrology: The case of physically-based models, Journal of Hydrology, 1987, 105, pp.257-172.

6. W. Ye, B. Bates, N. Viney, M. Sivapalan ,A. Jakeman, Performance of conceptual rainfallrunoff models in low-yielding ephemeral catchments, Water Resources Research, 1997,33, pp.153-166.

7. C. Fetter, Applied hydrogeology. Macmillan College Publishing Company Inc., 4th Edition, 2001.

8. A. Freeze, A, Cherry, Groundwater. Prentice Hall. Englewood Cliffs, New Jersey, 1979, 
pp.604.

9. J. Salas, Analysis and Modelling of Hydrologic Timeseries. Maidment, D. R., ed., Handbook of Hydrology, New York1992.

10. M. Shaw, Hydrology in Practice. Second Edition. Chapman and Hall, 1988, p.539.

11. N. Palivos, Geomorphological study of Atalanti area of Fthiotida prefecture. PhD Thesis Dissertation, School of Sciences, Department of Geology, Athens,2001.

12. D. Pantosti, P. DeMartini, D. Papanastassiou, N. Palyvos, F. Lemeille, G. D'Addezio, L. McNeill, K. Gaki-Papanastassiou, G. Stavrakakis, Geomorphological and paleoseismological studies of the Atalanti fault. XXVII Gen. Assembly of the Eur. Seism. Comiss., Lisbon Univ., Lisbon, 2000,p.73.

13. I. Lappas, I. Hydrogeological Regime of Loutraki Basin Focused on the Metallic Aquifer Characteristics and the Determination of Protection Zone. M.Sc. Thesis, School of Civil Engineering, N.T.U.A., Athens, 2004.

14. I. Lappas, Applied hydrogeological research in coastal aquifers. Case study of the coastal part of Atalanti region, Prefecture of Fthiotida. PhD Thesis Dissertation, School of Mining and Metallurgical Engineering, National and Technical University of Athens,2018 p.487.

15. I. Lappas, V. Tsioumas, V. Zorapas, Spatial - Temporal Analysis, Variation and Distribution of Precipitation in the Water District of Central - Eastern Greece. Bulletin of the Geological Society of Greece, vol.XLVII, Proceedings of the 13th International Congress, Chania, 2013.

16. I. Lappas, V. Tsioumas, V. Zorapas, K. Kaloumenos, Estimation and surface distribution of climate indices in the Water District of Central - Eastern Greece. Proceedings of the $10^{\text {th }}$ Hydrogeological Congress, 2014.

17. J. Davis, Statistics and data analysis in Geology. John Wiley and Sons, New York, 2002.

18. K. Kitanidis, Introduction to Geostatistics: Applications in Hydrogeology, Cambridge University Press, 1997.

19. G. Maratos, K. Rigopoulos, A. Athanasiou,. Geological maps of Atalanti and Livanates sheets, scale 1:50.000, Institute of Subsurface Geological Research.1965.

20. B. Andronopoulos, Geological - Tectonic study of Atalanti region. Athens, 1994,.

21. A. Ganas, Mapping of active normal faults in the Lokris region (Central Greece) using spot DEM data. Bulletin of the Geological Society of Greece, 1998,vol.XXXII/1, pp.173-179, Patra.

22. Th. Rondoyianni, J. Papadakis, Geological - seismotectonic conditions of the Atalanti area. I.G.M.E., Athens, 1986.

23. E. Zagana, Ch. Kuells, P. Udluft, C. Constantinou, Methods of groundwater recharge estimation in eastern Mediterranean: a water balance model application in Greece, Cyprus and Jordan. Hydrol Process, 2007,21, (18), pp.2405-2414.

24. L. Penman, Natural evaporation from open water, bare soil and grass. Proc. Roy. Soc. London A1948, (194), pp.120-145.

25. F. Blaney, G. Criddle, Determining water requirements in irrigated areas from climatic data. U.S. Dep. Agric., Soil Conservation Serv., Washington D.C.1950, p.96. 
26. H. Hargraeves, Estimating potential evapotranspiration. ASCE, J. Irrigation and Drainage Division,1982, 108(3), pp.225-230.

27. J. Doorenbos, W. Pruit, Crop Water Requirements. Irrigation and Drainage paper 24, U. N., Food and Agriculture Organization, Rome, Italy, 1977,.

28. B. Priestley, R. Taylor, On the assessment of surface heat flux and evaporation using largescale parameters. Monthly Weather Review, 1972, 100 (2), pp.81-92.

29. L. Turc, Nouvelle formule pour le calcul du bilan de l'eau en function des valeurs moyennes annuelles des precipitations et de la temperature. Ac. Sc.1951, Vol. 233.

30. L. Turc, Le bilan d'eau des sols: relations entre les precipitations, l'evaporation et l' ecoulemnent. Ann. Agron., 1954, pp.491-596.

31. L. Turc, Evaluation des besoins en eau d'irrigation, évapotranspiration potentielle, formula climatique simplifiée et mise à jour. Ann. Agron.1961, Vol. 12, pp.13-49.

32. M. Santoro, Sulla applicabilita della formula di Turc per il calcolo dell evapotraspirazione effective in Sicilia. Atti I Convegno International delle Acque Sotterranee, International Association of Hydrology, Palermo,1970, pp.123-140.

33. A. Coutagne, Quelques considerations sur le pouvoir evaporant de l'atmosphere, le deficit d'ecoulement effectif et le deficit d'ecoulement maximum, La Houille Blanche, 1954, pp.360-374.

34. D. Burdon, N. Papakis, Handbook of Karst Hydrogeology with special reference to the carbonate aquifers of the Mediterranean region. FAO, U.N. Special Fund, Institute for Geology and Subsurface Research, Greece, 1963,p.263.

35. D. Koutsoyiannis, A generalized mathematical framework for stochastic simulation and forecast of hydrologic timeseries. Wat. Resour. Re.2000, 36(6), pp.1519-1534.

36. K. Voudouris, P. Georgiou, Th. Mavtromatis, Ch. Gianneli, Comparison of actual evapotranspiration estimation methods: Application to Korisos basin, NW Greece. Evapotranspiration, Nova Science Publishers, 2013,pp.13-24.

37. K. Tilahun, B. Merkel, Estimation of groundwater recharge using a GIS-based distributed water balance model in Dire Dawa, Ethiopia. Hydrogeology Journal, 2009, 17, pp.14431457.

\section{* Corresponding Author: Lappas Ioannis}

Dr. Hydrogeologist, General Secretariat of Natural Environment and Water, Department of Protection and Management of Water Environment, Division of Surface and Ground Waters, Amaliados 17 Str., Ambelokipi-Athens, P.C.

11523 